\title{
ANALYZING STOCK LOCK-UPS: DO TARGET TREASURY SALES FORECLOSE OR FACILITATE TAKEOVER AUCTIONS?
}

\author{
Ian Ayres*
}

In negotiating his controversial takeover of the Trans Union Corporation (Trans Union), Jay A. Pritzker proposed an initial offer of $\$ 55$ per share. ${ }^{1}$ The Chief Executive Officer of Trans Union, Jerome W. Van Gorkom, responded that:

to be sure that $\$ 55$ was the best price obtainable, Trans Union should be free to accept any better offer. Pritzker demurred, stating that his organization would serve as a "stalking horse" for an "auction contest" only if Trans Union would permit Pritzker to buy [treasury] shares of Trans Union at market price which Pritzker could then sell to any higher bidder. ${ }^{2}$

Ultimately, Pritzker entered into an agreement with Trans Union in which Pritzker agreed to make a $\$ 55$ cash offer to Trans Union stockholders and in return Trans Union agreed to sell Pritzker one million treasury shares at the premerger market price of $\$ 38$ per share. ${ }^{3}$ While

* Assistant Professor, Northwestern University; Research Fellow, American Bar Foundation. B.A., Yale University; J.D., Yale Law School; Ph.D. (Economics), Massachusetts Institute of Technology. Discussions with Bernard Black, David Haddock, and Reinier Kraakman significantly improved the quality of this Article. Kieth Hylton, Gary Lawson, Geoffrey Miller, Peter Siegelman, and David Van Zandt provided helpful comments. The support of Northwestern's Corporate Counsel Center is gratefully acknowledged. Rebecca Ritchells provided excellent research assistance.

1. Smith v. Van Gorkom, 488 A.2d 858, 867 (Del. 1985). Jerome W. Van Gorkom, Trans Union's Chief Executive Officer, suggested not only the transaction but the takeover price. 1d. at 866. The Van Gorkom opinion refers to Pritzker as "a well-known corporate takeover specialist and [Van Gorkom's] social acquaintance." ld.

2. Id. at 866 .

3. Id. at 868 . Treasury shares are issued shares of stock held by the issuing corporation following their repurchase from the public. See NYSE Listed Company Manual, Glossary of Frequently Used Terms, vi (1983) (definition of treasury stock). In the Trans Union takeover, Pritzker bought authorized but unissued shares. Because treasury shares increased the corporation's paid-in capital, the difference between treasury shares and authorized but unissued shares historically was relevant to legal restrictions which prohibited corporations from distributing paid-in capital as dividends. See B. Manning, A Concise Textbook on Legal Capital 45, 130-32 (2d ed. 1981). For the purposes of this Article, however, there is no difference between the two types of shares and the term "treasury share" will be used throughout.

A target management may prefer to sell either treasury or "authorized but unissued" shares, because shareholders must approve any increase in the number of authorized shares. See, e.g., Del. Code Ann. tit. 8, § 242(a)(3), (b)(1)-(2) (1983); Revised Model Bus. Corp. Act $\S \S 2.02(a)(2), 10.03$ (1984). lt may be difficult for target management to gain approval for such a sale: "During a bidding war, of course, the sharehold. ers would not approve [a lock-up] deal, but would prefer a free and unhampered auction for their shares." R. Clark, Corporate Law § 13.6, at 573 (1986). Moreover, corporations tbat trade on the New York Stock Exchange may not increase the amount of out- 
some members of Trans Union's senior management initially objected to the deal, claiming that it amounted to a "lock-up" which "would inhibit other offers," 4 the deal eventually went on to fruition, and ultimately, litigation. ${ }^{5}$ In a "lock-up" merger agreement, a bidder's tender offer is conditioned upon the bidder's receiving the option to purchase treasury shares of the target corporation at a price below the tender offer. ${ }^{6}$ The term "lock-up" seems to derive from the perception that such agreements "lock-out" other potential bidders that find it economically infeasible to enter competing bids for the diluted stock.

Target corporations have employed the tactic of selling treasury shares to friendly bidders in several takeover contexts, ${ }^{7}$ leaving the courts to struggle with the issue of whether treasury sales should be enjoined because they "lock-up" the bidding process. ${ }^{8}$ This Article takes up the question by examining whether selling treasury shares to a bidder forecloses or facilitates competitive bids by third parties. By analyzing the bidders' incentives, this Article assesses whether selling

standing common stock by more than $20 \%$ percent without shareholder approval. NYSE Listed Company Manual § 312.03(c) (1989).

4. 488 A.2d at 867-68. The Delaware Supreme Court did not address the substantive propriety of selling treasury shares. Instead, the decision focused on the process that Trans Union used in accepting the Pritzker offer - that the decision "to approve the proposed cash-out merger was not the product of an informed business judgment." Id. at 864. Commentators have found the decision highly controversial. Compare Fischel, The Business Judgment Rule and the Trans Union Case, 40 Bus. Law. 1437 (1985) (arguing that business judgment rule should have protected Trans Union directors) with Macey \& Miller, Trans Union Reconsidered, 98 Yale L.J. 127 (1988) (arguing that Van Gorkom court correctly decided liability issue, but asserting that court's holding only should be applied in the takeover context). The Delaware legislature reacted to the Van Gorkom decision by passing an indemnification statute which allows corporations to indemnify their directors from shareholder derivative liability. Del. Code Ann. tit. 8, $\S 145$ (1983 \& Supp. 1988); see also id. § 102(b)(7) (allowing corporations to limit director liability in certain circumstances).

5. Smith v. Pritzker, No. 6342, 1982 WL 8774 (Del. Ch. July 6, 1982), rev'd sub nom. Smith v. Van Gorkom 488 A.2d 858 (Del. 1985).

6. See R. Clark, supra note 3, §.13.6, at 573 .

7. See, e.g., Treadway Cos. v. Care Corp., 638 F.2d 357, 366 (2d Cir. 1980) (sale of treasury shares to white knight accounting for $19.4 \%$ of outstanding shares); Frantz Mfg. Co. v. EAC Indus., 501 A.2d 401, 403-06 (Del. 1985) (transfer of treasury shares to employee stock ownership plan in order to dilute raider's control); Hecco Ventures v. Sea-Land Corp., No. 8486, 1986 WL 5840 (Del. Ch. May I9, 1986) (option to purchase treasury shares equal to $25 \%$ of outstanding shares).

8. Compare Data Probe Acquisition Corp. v. Datatab, Inc., 722 F.2d 1 (2d Cir. 1983) (option to purchase treasury shares amounting to $66 \%$ of target upheld against Williams Act challenge), cert. denied, 465 U.S. 1052 (1984) and Hastings-Murtagh v. Texas Air Corp., 649 F. Supp. 479 (S.D. Fla. 1986) (lock-up provisions upheld pursuant to business judgment rule) with Mobil Corp. v. Marathon Oil Co., 669 F.2d 366 (6th Cir. 1981) (lock-up option to buy treasury shares representing $17 \%$ of outstanding shares enjoined), cert. denied, 455 U.S. 982 (1982). See also Buffalo Forge Co. v. Ogden Corp., 555 F. Supp. 892 (W.D.N.Y.) (prevailing bidder's action for rescission of treasury stock sale to white knight denied), aff'd 717 F.2d 757 (2d. Cir.), cert. denied, 464 U.S. 1018 (1983). 
treasury shares can lead to higher takeover bids, and ultimately, whether target managers selling treasury shares are maximizing their shareholders' welfare.

A large class of treasury sales will not impede the target's sale to the highest valuing bidder. Additionally, treasury sales can facilitate the establishment of a takeover auction for the target thus benefiting shareholders. This target strategy, however, is not without cost. Although a treasury sale may be a prerequisite for an auction, selling treasury shares causes all auction participants to lower their maximum bids. Moreover, extreme forms of treasury sales ${ }^{9}$ can foreclose third parties with higher target valuations from making competitive bids. In sum, target shareholders benefit from treasury sales if a takeover auction with lower bids is better than no auction at all. This Article, therefore, proposes a test for when treasury sales cause foreclosure. Because foreclosure is inconsistent with maximizing shareholder welfare, the Article argues that courts should enjoin or rescind such sales. ${ }^{10}$

This Article is in four parts. Part I examines how a treasury sale lowers the reservation price, i.e., the maximum bid, of all potential bidders. ${ }^{11}$ Part II shows how, irrespective of this downward pressure on the prevailing maximum bid, treasury sales can create a takeover auction that may benefit target shareholders. Part III examines the possibility of foreclosure and proposes a practical standard for determining whether a treasury sale forecloses third parties from entering an auction. Such foreclosure represents an agency cost in which target management places its own interests in incumbency before the shareholders' interest in maximizing share value.

Part IV discusses additional applications of the analysis developed earlier in the Article. Specifically, Part IV considers the close analogy between treasury share sales and greenmail share purchases. Treasury sales, like greenmail, compensate initial bidders for investments in information. Treasury sales, however, have an added advantage in that

9. As detailed below, see infra text accompanying note 49 , a treasury sale becomes more "extreme" as the number of treasury shares sold increases or as the price at which the bidder buys these shares decreases.

10. This foreclosure standard for reviewing director conduct would govern even in the presence of a provision in the target corporation's articles of incorporation detailing the circumstances under which treasury sales would be allowed. In that sense, the proposed legal standard is an "immutable" rule. See infra notes 76-80 and accompanying text. See generally Ayres \& Gertner, Filling Gaps in Incomplete Contracts: An Economic Theory of Default Rules, 99 Yale L.J. 87 (1989) (discussing when default rules are appropriate and when immutable rules are preferred). Corporations would retain, however, the ability to adopt restrictions on treasury sales more stringent than the standard proposed in this Article. See infra notes 76-77 and accompanying text.

11. The reservation price is the highest price a bidder would be willing to pay at an auction. See S.M. Scherer, Industrial Market Structure and Economic Performance 17 (2d ed. 1980). 
they increase the probability that the target will ultimately be taken over at a premium. Consequently, Part IV questions earlier analysis suggesting that greenmail might be welfare enhancing, ${ }^{12}$ and suggests that target management's choice of greenmail when the superior auction-creating device of treasury sales exists borders on prima facie evidence of target management male fide.

Part IV also considers the sale of treasury shares to subsequent bidders or "white knights." Although a treasury sale to a white knight allows the target corporation to free-ride on the informational investments of the initial bidder, it can also be an efficient form of resistance to hostile offers by inducing third parties to investigate the target and by buying time more cheaply for the development of a takeover auction. Finally, Part IV extends the Article's analysis to asset lock-ups and ancillary provisions of treasury sales, such as restrictions on the release of proprietary information, that can inform a court's scrutiny of target managements' business judgment.

\section{The Ex Post lncentives}

\section{A. The Effect of Treasury Share Sales on the Initial Bidder}

To understand how treasury shares affect the incentives of an initial bidder, consider again the sale of 1 million treasury shares to Jay Pritzker as a condition of his $\$ 55$ single-tier, ${ }^{13}$ all-cash bid for Trans Union. The starting point of the analysis is to realize that as the sale price of Trans Union is bid up, Pritzker's profits from winning the auction decrease 14 but that his profits from losing the auction and "cashing in" his treasury shares increase. ${ }^{15}$ At some point Pritzker will have no incentive to match third-party bids because the profits from tendering

12. See Macey \& McChesney, A Theoretical Analysis of Corporate Greenmail, 95 Yale L.J. 13, 43-48 (1985).

13. Single-tiered or any-and-all takeover bids are made for $100 \%$ of the target company stock at a uniform price. See id. at 20; cf. Barron's Dictionary of Finance and Investment Terms 449 (2d ed. 1987) (contrasting definition of two-tiered bids with anyand-all bids). In contrast, two-tiered bids consist of a first tier offer to buy a controlling block of the target's stock at a per share price which is higher than the second tier offer to buy the remaining shares. See, e.g., Radol v. Thomas, 534 F. Supp. 1302, 1305 \& n.2 (S.D. Ohio 1982) (cited in Macey \& McChesney, supra note 12, at 19 n.26). See generally R. Clark, supra note $3, \S 11.2$ (collecting and analyzing arguments regarding twotier offers). Two-tiered offers are analyzed in the appendix, see infra p. 716. As discussed there, the effect of treasury sales is not substantively changed.

14. Pritzker earns less on the original outstanding shares because he must pay a higher purchase price. The higher purchase price for the treasury shares, however, does not affect Pritzker's profits if he is successful. From Pritzker's perspective, the purchase of the treasury shares is a "wash" should he win the auction because in "tendering" treasury shares to himself, Pritzker will realize only the capital he paid in. Since Pritzker is on both sides of the transaction, what Pritzker "the seller" earns on the discounted treasury shares equals what Pritzker "the buyer" loses. See infra note 20.

15. Higher bids increase Pritzker's profits from losing a takeover because Pritzker will be able to tender his newly purchased treasury shares to the auction "winner" for an 
the treasury stock will exceed the profits of a takeover. Most importantly, Pritzker will reach this indifference point before the bidding reaches his valuation of Trans Union because as the bidding approaches his reservation price Pritzker's profits from a takeover approach zero while his profits from losing the takeover continue to increase. This tradeoff is displayed in Figure 1 in which the takeover profits and the treasury share profits for Pritzker are graphed for various bids.

\section{Figure 1: How Treasury Share Purchases Affect Bidder Profits}

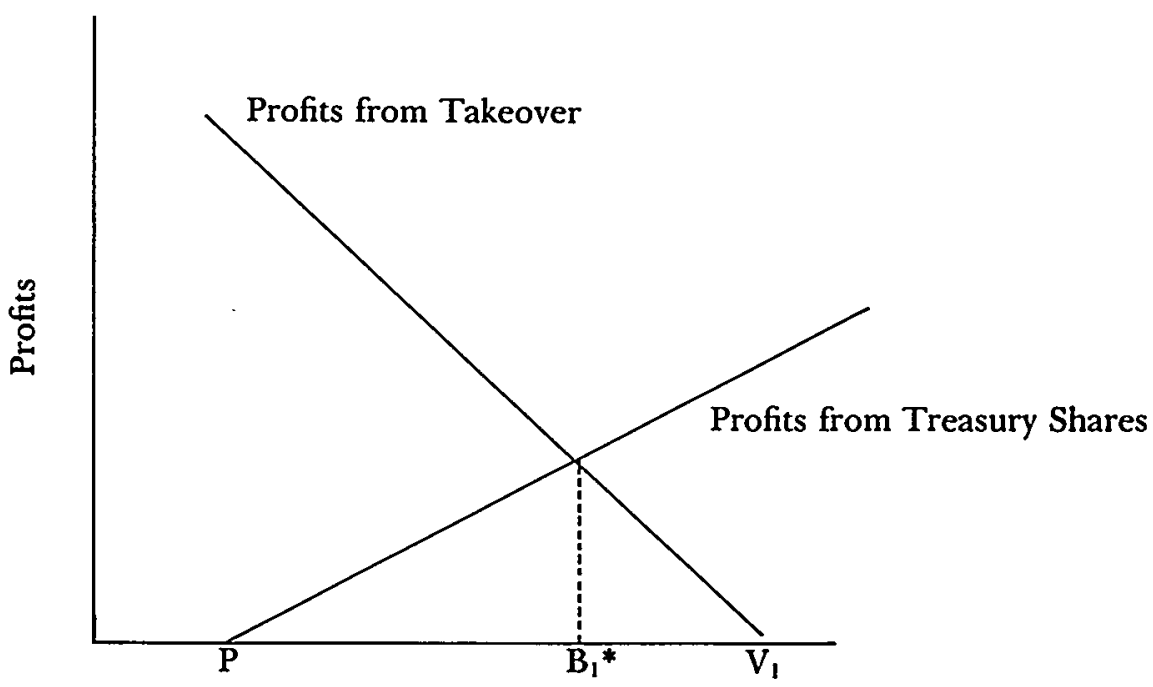

Bids

Assuming that the value of the firm to Pritzker $\left(V_{l}\right)$ is $\$ 60$ per share, the profits from takeover become progressively smaller as Pritzker raises his bid. For example, if Pritzker raised his bid to $\$ 60$, there would be no profit from the takeover because Pritzker would pay $\$ 60$ for stock that he valued at $\$ 60$. Higher bids by third parties, however, would increase the profits that Pritzker would earn from the treasury shares because Pritzker could tender those shares for higher prices.

Consequently, Pritzker has an incentive to match a third-party bid only when the profits from takeover are greater than the profits from 
tendering treasury shares to a third-party bidder: As shown in Figure 1, there exists a point $\left(B_{1}^{*}\right)$ below Pritzker's reservation price at which the profits from losing the takeover (and tendering) begin to exceed the profits from winning the takeover. The intersection of these two profit lines thus determines the maximum amount that Pritzker will bid in response to competing bids from third parties.

More generally, we can derive the maximum bid that the purchaser of treasury shares will make with a little algebra. Let:

$N=$ the number of original outstanding target shares,

$V_{1}=$ the per share value to the initial bidder,

$P=$ the price of treasury shares,

$T=$ the number of treasury shares,

$B_{I}=$ the initial bidder's bid, and

$B_{3}=$ the third party's bid.

The profits to Pritzker from winning the takeover bidding contest equal:

(1) $\left(V_{1}-B_{1}\right) N$,

and the profits to Pritzker from losing the takeover contest and tendering the treasury stock to a third-party are:

(2) $\left(B_{3}-P\right) T$.

Because Pritzker would only be willing to match (or slightly beat) a higher third-party offer if the profits from winning the takeover exceeded the profits of tendering the treasury stock, the maximum amount Pritzker would bid can be derived by setting equation (1) equal to equation (2) and solving for a common $B$. With a little algebraic manipulation, this maximum bid $\left(B_{1}^{*}\right)$ equals:

(3) $B_{1}^{*}=\left(V_{1} N+P T\right) /(N+T)$.

$B_{1}^{*}$ represents Pritzker's reservation price for the target after the purchase of treasury shares and corresponds to the intersection of the two profit lines in Figure 1. Intuitively, the profits from the treasury shares will be larger if there are more treasury shares or if the treasury price is lower, so that either an increase in the number of treasury shares or a reduction in the treasury price will decrease $B_{1}^{*}$, the maximum bid amount. ${ }^{16}$

Before buying any shares, a rational bidder should be willing to bid

16. By inspecting equation (3), we see that $B_{l}^{*}$ will increase as either $V_{l}$ or $P$ increases. By taking the derivative of equation (3) with respect to $T$ and $N$ we find that $B_{I} *$ will increase as $N$ increases but decrease as $T$ increases. These derivatives are: 
up to $V_{1}$ per share to take over the company. ${ }^{17}$ The purchase of treasury stock reduces the amount that a rational bidder would be willing to bid because $B_{1}^{*}$ is strictly less than $V_{1}$ :

(4) $\quad V_{1}-B_{1}^{*}=T\left(V_{1}-P\right) /(T+N)>0$.

Treasury purchases thus effectively reduce a rational bidder's reservation price for the company. If a bidding war ensues, the purchaser will start preferring loss to victory before the auction reaches $V_{l}$, the treasury purchaser's valuation. ${ }^{18}$ Bidders with treasury shares bid less because there is an opportunity cost associated with increasing their bids. ${ }^{19}$ Raising their bid (and thereby possibly winning the auction) forgoes the possibility of profiting from the treasury shares because bidders profit from the treasury shares only if they lose the auction. ${ }^{20}$ The purchaser of treasury shares therefore commits itself to bidding less than its per share valuation of the target. ${ }^{21}$

The foregoing analysis can be applied directly to the facts of Pritzker's takeover of Trans Union as developed in the Delaware Supreme Court's Smith v. Van Gorkom ${ }^{22}$ decision. The trial record indicates that approximately thirteen million shares were initially outstanding, and that Pritzker bought one million authorized but unissued shares for $\$ 38$ per share, so that $N=13$ million; $T=1$ million; and $P$ $=\$ 38 .{ }^{23}$ While Pritzker never explicitly revealed what Trans Union

$$
\left.d B_{1}^{*} / d T=N\left(P-V_{I}\right) / T+N\right) 2<0 ; \text { and }
$$

$\left.d B_{l}^{*} / d N=T\left(V_{l}-P\right) / T+N\right) 2>0$.

17. Formally, a rational bidder would be willing to bid up to an amount slightly less than its value, $V_{I}-\epsilon$, where $\epsilon$ is an arbitrarily small number.

18. Because the profit line in Figure 1 for losing the takeover is upward sloping, the intersection which defines $B_{1}^{*}$ must be to the left of $V$.

19. "Opportunity cost" can be defined as "the price that you pay for things that you might have done." B. Joel, Only the Good Die Young (1977).

20. Bidders with treasury shares earn no extra profits if they win the auction. If the bidders win the auction, they recover the capital generated by the sale of these shares, but this capital is their own money. This can be demonstrated with the use of a little algebra: without a treasury share sale, a bidder pays $B_{I} N$ for a firm that it values at $V_{A} N$. With a treasury share sale, a bidder pays $B_{l} N+P T$ for a firm that it values at $V_{l} N+P T$. In either case, the profits from winning the auction will be $\left(V_{1}-B_{1}\right) N$.

For a two-tiered bid, the purchase of treasury shares can increase the profits from winning because the bidder can reduce the number of shares included in the higher cost front-end from $N / 2$ to $(N-T) / 2$.

21. As calculated in equation (4), the magnitude of this reduction in the reservation price is a positive function of the number of pre-tender shares purchased and the bidder per share valuation, and a negative function of the pre-tender purchase price and the number of outstanding shares. These results can be calculated by taking the derivative of equation (4) with respect to its component parts. For example, the derivative of this equation with respect to the number of purchased treasury shares, $T$, equals:

$N\left(V_{1}-P\right) /(T+N) 2$.

22. 488 A.2d 858 (Del. 1985).

23. Id. at 867. The opinion indicates that "Van Gorkom multiplied [\$55] per share by the number of sbares outstanding to reach a total value of the Company of $\$ 690$ million." 1d. at 866. This implies that there were I2.54 million shares outstanding 
was worth to him, Donald Romans, Trans Union's Chief Financial Officer, had estimated the per share value to be between $\$ 55$ and $\$ 65 .^{24}$ If we again assume that Trans Union was worth $\left(V_{l}=\right) \$ 60$ per share to Pritzker, ${ }^{25}$ then we can calculate the effect of selling the treasury shares to Pritzker. By substituting these values into equation (3), we see that after buying the treasury shares Pritzker would not have any incentive to raise his bid above $\left(B_{1}^{*}=\right) \$ 58.43$-even though he thought Trans Union was worth $\$ 60$ per share. If a third party had bid higher than $\$ 58.43$, Pritzker would have preferred to profit from tendering the treasury shares.

All the facts in this analysis are readily available from the trial record except for $V_{l}$, Pritzker's valuation of Trans Union. Since Pritzker did not (and indeed could not credibly) notify the market of how much the shares were worth to him, third parties could not have determined Pritzker's reservation price $\left(B_{I}^{*}\right)$ with precision. Third party estimates of $B_{I}^{*}$ will turn, like ours, on independent estimates of intrinsic value of the type provided in the Van Gorkom decision. ${ }^{26}$

In addition to lowering the maximum bid the treasury share recipient will make, the purchase of treasury shares also serves to guarantee the recipient a minimum profit from the takeover. In the Trans Union context, for example:

(a) If no one matches Pritzker's original $\$ 55$ bid, Pritzker will win the auction and earn $\$ 65$ million (from equation (1), $(\$ 60-\$ 55) 13$ million);

(b) If a third party tenders a competing bid less than or equal to $\$ 58.43$, Pritzker will respond with a slightly higher bid

(\$690 million/ $\$ 55)$. For computational simplicity, the textual analysis assumes 13 million shares outstanding. Id. at 866.

24. Id. at 867 .

25. It is reasonable to expect that Pritzker would bid less than his true value-so that he would make $\$ 5$ per share on his original $\$ 55$ bid.

26. From the fact that Pritzker was willing to offer $\$ 55$ we can deduce at least a lower bound for Pritzker's valuation $\left(V_{l}\right)$. Equation (3) calculates the maximum amount that a rational bidder with treasury shares would be willing to bid for the target $\left(B_{l}^{*}\right)$. Since the initial bid $\left(B_{l}^{\prime}\right)$ should be less than or equal to this maximum bid, one can derive a minimum estimate of Pritzker's value $\left(V_{I}^{\min }\right)$ by substituting known values into equation (3):

$$
B_{l}^{\prime}<B_{l}^{*}=[V, \mathrm{~N}+P T] /(N+T) \text {. }
$$

Solving this inequality for $V_{I}$ yields $V_{I}^{\min }$, the minimum per share value for a rational bidder:

$$
V_{l}^{m m}=\left[B_{l}{ }^{\prime} N+T\left(B_{l}{ }^{l}-P\right)\right] / N .
$$

Substituting the values for the Trans Union takeover indicates that Pritzker must have at least valued Trans Union at $\$ 56.31$ per share if he was willing to bid $\$ 55$ following the treasury sale:

$$
V_{l}^{m i n}>\$ 56.31 \text {. }
$$

In discussing the possibility of foreclosure, this Article will show that the initial offer $B_{I}^{l}$ can at times be greater than $B_{I}^{*}$. See infra note 49 and accompanying text. 
and profit by taking over Trans Union for less than his values (\$60); and

(c) If a third-party enters a competing bid greater than $\$ 58.43$, Pritzker will not match it, but will still profit by tendering his treasury shares.

In any case, Pritzker is "guaranteed" at least the amount of profit at the intersection of the lines in Figure 1. At that point Pritzker would be indifferent between taking over the firm and letting third parties prevail. These guaranteed profits can be derived from either equation (1) or (2) to equal:

$$
\left(V_{1}-B_{1}^{*}\right) N=\left(B_{1}^{*}-P\right) T .
$$

In Van Gorkom, Pritzker would have been guaranteed at least $\$ 20.4$ million whether or not he won a bidding war with third parties. From Pritzker's perspective, the treasury shares can be viewed as a form of auction insurance. Even if Pritzker loses the auction he will receive more than $30 \%$ of the profits from taking over the firm for $\$ 55$ per share $(\$ 20.4$ million $/ \$ 65$ million $=.313)$.

As shown in Figure 1, the sale of treasury stock to Pritzker created a "profit valley"- a guaranteed profit at the bottom but higher profits on either side. Accordingly, Pritzker would not want to enter into a bidding war with third parties unless he were either going to win big or lose big. Indeed, Pritzker theoretically might have incentives to bid higher than $B_{1}^{*}$ if he felt that he could force a competing third party to bid higher. Under this scenario, Pritzker would be like the shill at an auction, acting as an agent of the seller to bid up the price, while trying actually not to buy. Pritzker, like the shill, would then receive a cut of the higher auctioned sale price-Pritzker's cut coming in the higher value of his treasury shares. But this is a risky strategy if Pritzker did not know what the third parties are willing to pay. The risk that Pritzker might end up buying the corporation should greatly undermine Pritzker's incentives to bid above $B_{1}$.

\section{B. The Effect of Open Market Purchases on the Initial Bidder}

The analysis changes significantly when a bidder acquires outstanding shares on the open market ${ }^{27}$ because while treasury share purchases reduce a bidder's reservation price, open market purchases do not. Bidders that purchase treasury shares profit from the treasury shares only if they lose the auction. ${ }^{28}$ Winning bidders do not profit from owning treasury shares because they merely tender these addi-

27. The Williams Act allows potential bidders to buy up to five percent of a company's outstanding stock before declaring a tender offer. 15 U.S.C. $§ 78 n$ (d) (1988). Bidders routinely take advantage of this rule and buy as many shares as possible at the lower pre-tender offer price.

28. See supra note 20 and accompanying text. 
tional shares to themselves. ${ }^{29}$ A rational bidder's reservation price is reduced to account for the opportunity cost associated with winning an auction.

Winning bidders $d o$ profit from open market purchases, however, because these lower-priced purchases reduce the number of shares that need to be purchased at the higher tender offer price from other shareholders. Bidders purchasing shares on the open market thus profit from these purchases whether they win or lose the auction so that open market purchases do not engender the same sort of opportunity cost. Moreover, the bidders' profit, the difference between the purchase price and the tender price, is the same whether the bidders tender the open market shares to a third party or "tender" the shares to themselves. A bidder making open market purchases, therefore, will continue to bid up to that bidder's particular valuation of the target.

For example, if Pritzker had purchased his million shares from the market, rather than from Trans Union's treasury, he should still be willing to raise his tender offer up to his per share valuation, $V_{l}$. At this price, he would not have profited from the tendered shares, but he would have gained $\left(V_{1}-P\right) T$ on the shares he had purchased on the open market (at price $P$ ). Thus, although Pritzker would have earned less on the tendered shares as the tender offer increased, his profit from the open market purchases would have been constant for any bid up to $V_{l}$. These effects are depicted in Figure 2.

Unlike the profits from treasury shares, the profits from open market shares are added to the profits from tendered shares to calculate the total profits from winning the takeover auction. The profits from winning the merger will equal the vertical sum of the profits from the tendered shares and the profits from the open market purchases:

$$
\text { (6) }\left(V_{l}-B_{l}\right)(N-T)+\left(V_{l}-P\right) T \text {. }
$$

The second term of equation (6) shows that the profits from the open market purchases are unaffected by the size of $B_{1}$ as long as the initial bidder wins the takeover auction.

If a third party bids $B_{3}>V_{1}$, then the initial bidder will prefer to lose the takeover contest and tender its open market shares for a profit of $\left(B_{3}-P\right) T$-represented in Figure 2 by the upward sloping Open Market Profits line. Following open market purchases, a bidder would still bid up to $V_{1}$ because only third-party bids above this amount cause a bidder to profit more from losing the takeover. Purchasing shares from the open market, therefore, does not lower the bidder's reservation price. ${ }^{30}$ As intuition would suggest, a person who believes the firm

29. See supra notes 14, 20.

30. From equation (6), we also can see that $V_{1}$ is the reservation price because the first term becomes negative if $B_{1}$ exceeds $V_{1}$, i.e., while the profit from the open-market purchases enables a bidder to bid above its reservation price and still earn a profit, the 
Figure 2: How Open Market Purchases Affect Bidder Profits

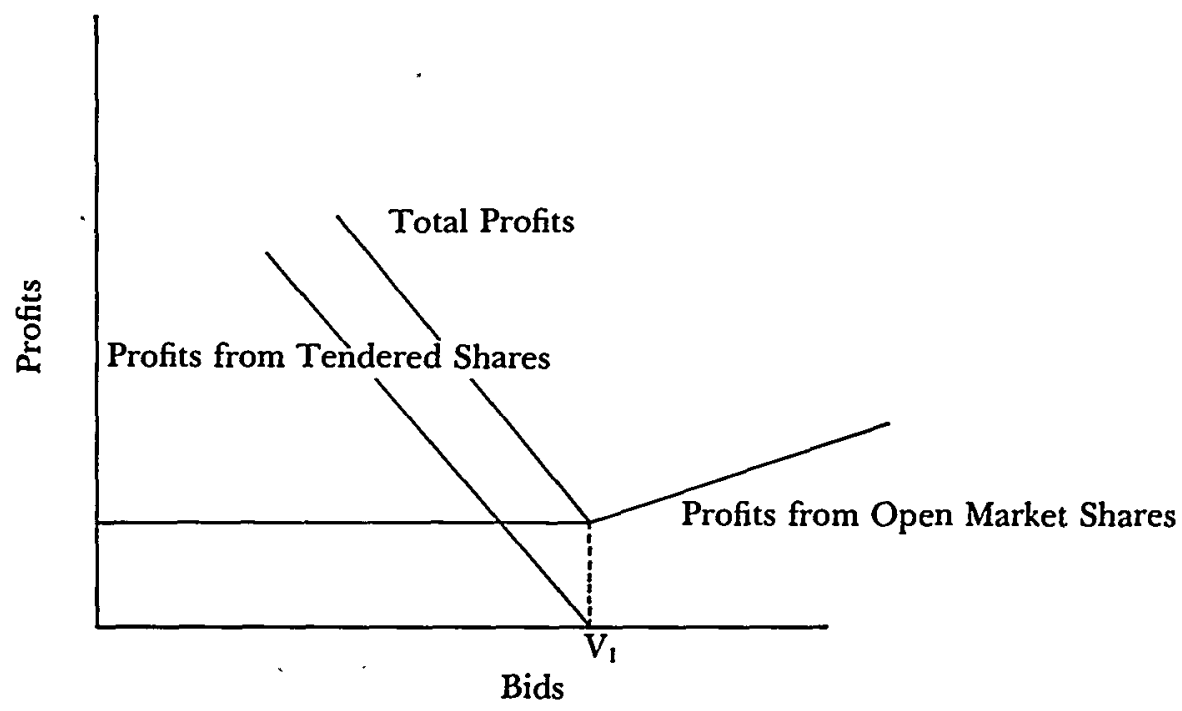

to be worth $V_{1}$ will have an incentive to bid up to $V_{1}$ for the firm. ${ }^{31}$ Thus, although treasury share purchases reduce an initial bidder's reservation price, open market share purchases do not.

Figure 2 indicates that open market purchases "guarantee" the initial bidder a minimum profit from the takeover auction, because even the lowest point of the profit valley insures positive profits. ${ }^{32}$ The second term of equation (6) indicates that, as is the case with treasury share purchases, this insurance flows from profits made on share purchases consummated outside of the tender offer transaction, $\left(V_{1}-\right.$

bidder will not do so because it can realize a larger profit by tendering its shares purchased on the open market to the higher-valuing third-party bidder.

31. There are models of the "winner's curse" in which bidders do not know with certainty what the firm will be worth to them. To compensate for the tendency for the auction winner to overbid (the curse), all bidders systematically reduce how much they will bid. See Black, Bidder Overpayment in Takeovers, 41 Stan. L. Rev. 597, 625 (1989).

32. A prospective bidder has an incentive to buy as much stock as it can at the pretender offer price because it is cheaper to buy the stock outside of the tender offer. The provision of the Williams Act which allows prospective bidders to purchase five percent of a target's outstanding stock before announcing a tender offer, 15 U.S.C. $\$ 78 \mathrm{n}$ (d) (1988), is analogous to the 17-year patent protection allowed by federal law. See 35 U.S.C. $\$ 154$ (1982). Both are limited grants of monopoly power that compensate individuals who invest to develop socially valuable information. 
$P) T$. The crucial difference between treasury share and open market purchases, however, is that with treasury share purchases the profit valley (and therefore the reservation price) is centered at $B_{1}^{*}$, while with open market purchases the reservation price remains fixed at $V_{l}{ }^{33}$

In sum, both open market and treasury share purchases "guarantee" a bidder a profit from a takeover auction whether or not the bidder ultimately enters the highest bid. These two sources of pre-tender offer shares, however, have dramatically different effects on a bidder's maximum bid. Open market purchases of target stock should not reduce a bidder's reservation price while treasury share purchases should. Bidders can only profit from treasury shares by losing an auction. This analysis shows that at some point in competitive bidding, rational bidders holding treasury shares will drop out of auctions at bids below their valuation $\left(B_{1}<V_{1}\right)$ because, as shown in Figure 1, they prefer to profit from their treasury shares rather than match a rival's bid. Raising a bid thus entails the opportunity cost of profiting on treasury shares. Courts have often failed to recognize this opportunity cost. $^{34}$ By purchasing treasury shares, a bidder effectively promises to drop out of subsequent auctions at a price below its subjective valuation. This commitment to a reduced reservation price will crucially inform our subsequent discussion of foreclosure.

\section{The Effect of Treasury Share Sales on Third-Party Bidders}

The preceding analysis suggests that the sale of treasury stock to bidders (such as Pritzker) lowers the maximum amount they would be willing to bid for a target company. This by itself indicates a form of "self-foreclosure": purchasing treasury shares might disadvantage the purchaser in any subsequent takeover auctions. To determine whether selling treasury stock to an initial bidder inhibits or facilitates the creation of an auction market, however, it is important to see how the treasury sale affects the maximum bids of third parties as well.

At first, it might seem that treasury stock purchases would raise a

33. These and the following results do not change if the initial bidder purchases shares from both the corporate treasury and the open market. Although both types of purchases guarantee a minimum profit from the takeover auction, only treasury share purchases reduce the bidder's reservation price. Thus, the foregoing analysis, see supra notes 14-21, applies to the "usual" situation in which the purchaser of treasury shares will also purchase the Williams Act limit from the open market. For simplicity, however, the subsequent analysis focuses on sales of treasury shares to bidders who own no other stock in the company.

34. In Mobil Corp. v. Marathon Oil Co., 669 F.2d 366 (6th Cir. I981), for example, the court struck down a stock lock-up because it was less costly for the recipient to raise its bid than for its rivals: "[E]very dollar raise in the bid by USS [the treasury share recipient] would cost USS $\$ 30$ million, while each such dollar raise would cost Mobil $\$ 47$ million." Id. at 375 . In reaching this conclusion, the court ignored the opportunity cost that USS faced in raising its bid-literally millions of dollars in foregone profits from tendering its treasury shares to the rival bidder, Mobil. 
third party's reservation price (maximum bid) because the initial bidder in purchasing treasury stock contributes real assets to the corporation (equalling $P T$ ). This initial intuition ignores, however, the fact that the treasury shares, as in the Trans Union example, are usually purchased at prices below the purchaser's tender offer. Selling these additional treasury shares at a price that does not include the post-merger synergistic value effectively "dilutes" the synergistic value of the outstanding shares, and thus reduces the maximum amount that a third party would be willing to bid. ${ }^{35}$

For example, in Van Gorkom the treasury sale required third parties to purchase 14 million shares of stock instead of the pre-sale 13 million shares. The diluting of synergistic value stands at the heart of the plaintiff's claim that the treasury sale "was a 'lock up' and amounted to 'an agreed merger as opposed to an offer.' "36 It is to this crucial claim that we now turn our attention.

Let the total value of the target to a third party equal $\mathrm{NV}_{3}$. Before a treasury sale to the initial bidder, the maximum amount that the third party would bid per share would be simply its per share value, $V_{3}$ :

(7) $V_{3}=N V_{3} / N$.

After the treasury sale to the initial bidder, however, this reservation price decreases because the third party has to buy more stock $(N+T)$, but the target corporation does not gain proportionally more assets. Thus, the third-party bidder has to buy $(N+T)$ shares of stock which it only values at $\left(\mathrm{NV}_{3}+\mathrm{PT}\right)$. Accordingly, the third party's maximum bid after the treasury sale, $B_{3}{ }^{*}$, falls to:

(8) $B_{3}^{*}=\left(N V_{3}+P T\right) /(N+T)$.

As described above, the synergistic value of the merged target (reflected in the fact that $V_{3}>P$ ) is diluted by the treasury sale. The sale causes a third party's reservation price to fall from $V_{3}$ to $B_{3}{ }^{*} .37$ This fall in a third party's maximum bid raises the possibility that the treasury sale may inhibit third parties from making competitive bids for the firm. The treasury sale not only reduces what the initial bidder is willing to bid for the target, but it also reduces what all third parties are willing to offer.

35. This is in contrast to open market purchases by an initial bidder which do not dilute the synergistic value and therefore do not affect the maximum amount that a third party would bid. Cf. supra pp. 690-92 (open-market purchases by initial bidder reduce the number of shares which must be purchased).

36. Smith v. Van Gorkom, 488 A.2d 858, 868 (Del. 1985).

37. The fall in reservation price:

$V_{3}-B_{3}^{*}=T\left(V_{3}-P\right) /(N+T)$,

is greater than zero if $V_{3}>P$. 


\section{Who Wins the Takeover Auction after a Treasury Sale?}

The question remains whether treasury sales foreclose third parties from making competitive bids. The foregoing analysis indicates that a third party ultimately will prevail only if its maximum bid is greater than the initial bidder's maximum bid:

$$
B_{3}^{*}>B_{1}^{*} \text {. }
$$

But under what conditions will this hold? Substituting for $B_{1}^{*}$ and $B_{3}^{*}$ from equations (3) and (8) discloses that a third party will ultimately prevail in a bidding war if and only if:

$$
B_{3}^{*}=\left(N V_{3}+P T\right) /(N+T)>B_{1}^{*}=\left(N V_{1}+P T\right) /(N+T),
$$

which simplifies to:

(9) $V_{3}>V_{1}$.

The straightforward interpretation of equation (9) is that third-party bidders will outbid the initial bidder holding treasury shares only if they value the firm more. But this is exactly the condition for a third party to prevail in takeover contests without sales of treasury stock. If a third party has a higher reservation price before a treasury sale, it will have a higher reservation price after the treasury sale. This striking result means that the sale of treasury stock lowers the reservations price of all , bidders but does so equally. The "diluting" costs of treasury sales for the third-party bidders is identical to the "opportunity" cost for the initial bidder. The "diluting" cost to the third-party bidder is the initial bidder's profit from losing the takeover. Counter to the arguments of the plaintiffs in Van Gorkom then, the sale of treasury stock does not need to foreclose higher-valuing bidders from outbidding the purchaser of treasury shares. The primary effect of the ordinary treasury sale on the ensuing auction contest, therefore, is not on who wins the auction, but on what the winning bid will be. Consistent with basic tenets of efficiency, the ownership of corporate assets- will travel to the highest valuer, but the treasury sale reduces the per share bid that wins the auction.

The following parts explore two caveats to this conclusion that treasury sales will not affect the ordinal ranking of parties' reservation prices. Part II argues that treasury sales may increase third-party reservation prices by giving interested parties additional time to investigate and finance a competitive bid. Part III then shows that unfaithful target management might actually induce a treasury share recipient to bid above its reservation price (as a condition for purchasing treasury shares) and thereby cause foreclosure. The tension between these two caveats will determine whether treasury sales are legitimate target tactics. 


\section{The Possibility of Facilitating a Takeover Auction: The Ex Ante Incentives for Treasury Share Sales}

The last Part analyzed the incentives of takeover bidders after a treasury share sale. Given these foreseeable ex post incentives, this part investigates whether it ever will be mutually advantageous ex ante for a target to sell treasury shares to a bidder. In particular, by analyzing the ex ante incentives for treasury share sales, we can directly assess whether target shareholders might gain from the transaction. This latter analysis is central to whether the directors are acting as faithful fiduciaries. ${ }^{38}$

An important conclusion of this section is that treasury sales can benefit shareholders. By persuading a bidder to hold its tender offer open for a longer time period, a target management may generate higher competing bids for the target stock. Timing is central to this story. Less time inhibits the ability of third parties to investigate and finance a competitive bid. ${ }^{39}$ Selling treasury shares to a bidder is a way that a target company buys time from the bidder. Although the treasury sale itself reduces the participants' reservation price for the target stock, an auction with reduced reservation prices may produce a higher bid for target shareholders than no auction at all.

But this additional time to create a takeover auction comes at a price. To rigorously demonstrate that a treasury sale is in the target shareholders' interest, it is necessary to show that the gains from the auction outweigh the costs of the treasury sale. Bidders, such as Pritzker, will demand compensation before they will serve as " stalking horse[s]' for an 'auction contest." "40 A bidder will agree to hold a tender offer open only if the expected profits from a takeover auction with treasury shares exceeds the expected profits of proceeding with an abbreviated tender offer without treasury shares. If bidders demand too much compensation, then target shareholders will not, on net, gain from "buying" a takeover auction. It is necessary, therefore, to show that the bidders will demand less than the shareholders are willing to offer. In short, it is necessary to show that there can be "gains from trade" in entering into a treasury share sale.

Treasury sales can create mutual gains if they increase the

38. Often, to evaluate the fidelity of target management, courts need to distinguish between actions aimed at keeping the incumbent target management in power (the management entrenchment hypothesis) and actions aimed at increasing shareholder wealth (wealth maximization hypothesis). See Macey \& McChesney, supra note 12, at 42-43.

39. See Easterbrook \& Fischel, The Proper Role of a Target's Management in Responding to a Tender Offer, 94 Harv. L. Rev. 1161, 1174, 1178-79 (1981); Haddock, Macey \& McChensey, Property Rights in Assets and Resistance to Tender Offers, $73 \mathrm{Va}$. L. Rev. 701 (1987); Macey \& McChesney, supra note 12, at 27 \& n.58.

40. Van Gorkom, 488 A.2d at 866 . Even when lock-up agreements do not explicitly compel a bidder to hold its tender offer open, treasury sales can facilitate takeover auctions by eliciting an initial bid which puts the target "in play." 
probability that third-party bidders will be found who value the target more than the treasury share recipient $\left(V_{3}>V_{l}\right)$. Without treasury shares, the initial bidder gains nothing from the entry of third parties into the auction contest. But after entering into a treasury sale agreement, both the initial bidder and the target shareholders can potentially gain from a third-party bid that is greater than the initial bidder's valuation.

This point can be illustrated with a simple example based, once again, on the Trans Union takeover. Without a treasury share agreement, Pritzker and the Trans Union management might have expected that Pritzker had a 50 percent chance of taking over Trans Union at his initial bid of $\$ 55$ per share, and a 50 percent chance of taking over the firm at $\$ 60$ per share (because intervening third-party bids would force him to raise his initial offer). The additional time created by a treasury share agreement, however, might have caused the parties to expect a 50 percent chance that a $\$ 65$ third-party bidder could be found (and again a 50 percent chance that Pritzker would take over Trans Union at \$55). Under these expectations, both Pritzker and the Trans Union shareholders are made better off by entering into the treasury share agreement. Without treasury shares Pritzker would expect to earn only $\$ 32.5$ million from the takeover $(.5(60-55) 13$ million), because he would only profit if he could take over Trans Union at a price less than his $\$ 60$ valuation. With treasury shares, however, Pritzker profits whether or not he wins the auction: Pritzker's total expected profits increase to $\$ 46$ million. ${ }^{41}$ The shareholders of Trans Union also gain from entering into the treasury share agreement. Without the agreement, the expected winning bid would be $\$ 57.5$ per share (an average of the possible $\$ 55$ and $\$ 60$ bids), but with the agreement they would expect to tender at $\$ 60$ (the average of $\$ 55$ and $\$ 65$ )..$^{42}$

The initial bidder's bargaining power in the foregoing analysis has been premised on its ability to quickly consummate a takeover if the

41. With treasury shares, Pritzker would again have a $50 \%$ chance to take over the firm at $\$ 55$ per share and a $50 \%$ chance to tender his treasury shares to a third party bidding $\$ 65$ per share. His total expected profits with treasury shares accordingly is:

$$
\begin{aligned}
& .5(60-55) 13 \text { million }+.5(65-38) 1 \text { million } \\
& =\quad 32.5 \text { million }+13.5 \text { million } \\
& =\$ 46 \text { million. }
\end{aligned}
$$

42. This analysis assumes that the initial bidder cannot costlessly resell the target firm to a higher bidder. If the initial bidder could costlessly resell the target, the potential existence of higher-valuing third-party bidders would increase $V_{I}$ because the initial bidder would include in its valuation the potential profits from resale. Both empirical and theoretical reasons exist, however, for expecting that the transaction costs of resale will not eliminate all gains from treasury share trade. See Gilson, Seeking Competitive Bids Versus Pure Passivity in Tender Offer Defense, 35 Stan. L. Rev. 51, 62-64 (1982); Macey \& McChesney, supra note 12, at 26 n.52. But see Easterbrook \& Fischel, Auctions and Sunk Costs in Tender Offers, 35 Stan. L. Rev. 1 (1982) (arguing that transaction costs of successive tenders are lower than the costs of auction). 
target fails to buy extra time. In some situations, however, this bargaining power may be severely limited. For example, if the target corporation has an effective poison pill agreement in place, ${ }^{43}$ it need not bargain for extra time (because the initial bidder will not want to consummate its offer until the management has rescinded the pill). Nevertheless, treasury sales can benefit target shareholders. Potential bidders may need to incur sunk costs to investigate the value of the target. These sunk costs may be lost if a third party wins the firm in a bidding contest. ${ }^{44}$ Treasury sales can compensate bidders for making this investment in information and more efficiently divide the risks and returns in making such investments. ${ }^{45}$

The possibility that treasury sales will generate gains from trade is heightened by the endogenous nature of these probabilities. The actions of both the target and the initial bidder can crucially affect the likelihood that higher-valuing third-party bidders will come forward. A treasury share agreement can invest both the target and the initial bidder in "producing" such higher-valuing bidders. A properly structured treasury share agreement will turn the initial bidder into a selling agent of the target shareholders. With the profits from treasury shares as a sales commission, the Pritzkers of the world may, paradoxically, even attempt to locate third-party bidders to outbid them. ${ }^{46}$

43. The term "poison pill" describes a range of defensive takeover tactics in which the target management commits to granting common shareholders preferred stock or discounted warrants if a tender offeror succeeds in acquiring a majority of the outstanding shares. See R. Clark, supra note 3, at 574-75. The tactic is "poisonous" to the offeror because a successful tender offer triggers massive dilution of corporate value.

44. The probability that a third party will win the auction, and that the initial bidder will lose its sunk costs of investigation, is especially great if free riding is possible. See infra note 83 .

45. A target also might induce bidder investment by promising a quick transaction (a short offer period) that maximizes the probability that the acquirer can take over the firm at $B_{l}^{\prime}$, the initial offer price. Quick transactions, however, deny both the target shareholders and the bidder the additional potential gains of selling to a higher-valuing third party. In addition, the Delaware Supreme Court's holding in Revlon, Inc. v. MacAndrews \& Forbes Holdings, Inc., 506 A.2d I73, I82 (Del. I986) (target directors must try to obtain the highest price possible for the company once they determine that a takeover is "inevitable") would appear to forbid such quick transactions. I would like to thank Reinier Kraakman for bringing these points to my attention.

46. Different probability assessments and different attitudes toward risk also can create gains from entering into treasury share agreements. For example, if the target managers believe more strongly than the initial bidder that additional time will generate high additional offers, then the parties will more likely be able to negotiate a treasury share agreement to extend the time for additional offers (because the target managers will believe that they can compensate the initial bidder for its additional costs, plus a substantial profit, and still expect to gain from the treasury sale). In addition, if the initial bidder is more risk averse than the diversified target shareholders, both sides may realize gains from the sale of "auction insurance" to the initial bidder. See supra text p. 690 (analogizing treasury sale as insurance). 


\section{The Possibility of Foreclosure: Standards FOR ANALYZING LOCK-UPS}

The foregoing analysis does not suggest that treasury share sales necessarily increase the welfare of target shareholders. ${ }^{47}$ If targets overcompensate the treasury share recipient either by selling too many treasury shares or by setting too low a striking price, then the shareholders can be hurt. Although target managers might enter into treasury share agreements to further their shareholders' interests, it also is possible that target managers will sell treasury shares solely to promote their own interests in retaining their jobs. If the target managers are unfaithful agents, they may choose to sell treasury shares to a bidder who implicitly promises to retain their services.

Courts need to establish standards that distinguish between faithful managers attempting to facilitate a more lucrative auction for their firm and unfaithful managers attempting to foreclose an auction by selling their firm to a bidder who will retain their services. The faithful manager's motive is to maximize shareholder wealth, while the motive of the unfaithful agent is to entrench target management. To distinguish between these competing hypotheses, this Part examines extreme forms of treasury sales that can foreclose higher-valuing bidders from a takeover auction. It then proposes a standard to distinguish treasury sales that facilitate takeover auctions from those that foreclose them.

\section{A. The Foreclosing Effect of Overinsurance: The Treasury Give Away}

Part II showed that treasury share purchases can be a form of auction insurance for bidders in that they would be guaranteed some profits even if they ultimately lost the ensuing bidding contest. ${ }^{48}$ If the treasury shares insure more than $100 \%$ of this takeover risk, however,

47. Returning to our earlier example, see supra note 41 and accompanying text, if the treasury sale created only a 10 percent chance that a $\$ 65$ third-party bidder would be found, Pritzker would still benefit from the sale:

$$
\begin{aligned}
& 0.9(60-55) 13 \text { million }+0.1(65-38) 1 \text { million } \\
& =\quad 58.5 \text { million }+2.7 \text { million } \\
& =\$ 61.2 \text { million; }
\end{aligned}
$$

but the Trans Union shareholders would be injured: Without the agreement, the expected winning bid would be $\$ 57.5$ per share (an average of the possible $\$ 55$ and $\$ 60$ bids), but with the agreement the shareholders would expect to tender for $\$ 56(0.9 \times$ $\$ 55+0.1 \times \$ 65)$.

48. The Delaware chancery court alternatively characterized the insurance aspects of the treasury sale:

[1]n the event of a higher bid being made for the stock of Trans Union, the Pritzkers would be compensated [by the treasury shares] to some extent by having issued what amounted to a 'put' to Trans Union, in that during the 90 to 120 days required to gain approval of the proposed merger, the Pritzkers would be contractually obligated to consummate the proposed merger, while Trans Union would remain free to accept a better offer. 
foreclosure of third-party bidders is possible. Higher-valuing bidders may be foreclosed if the target company guarantees that the recipient of treasury shares will profit more from losing the auction (and tendering its shares) than from winning the auction at its initial bid.

The possibility of foreclosure is depicted in Figure 3. In this graphed example, the treasury share agreement is so large that the initial bid, $B_{I}{ }^{\prime}$, is larger than the bidder's reservation price, $B_{1} * 49$ The initial bidder's profits from losing a takeover contest and tendering treasury shares grows as either the number of treasury shares $(T)$ increases or as the recipient's purchase price $(P)$ decreases. Accordingly, the size of a treasury share agreement increases if either $T$ rises or $P$ falls. ${ }^{50}$ In Figure 3, as the size of the agreement increases the treasury share profit line shifts upward. If the treasury sale involves either a large enough block of shares or a low enough striking price, then the treasury share profit line begins to intersect the takeover profit line to the left of the initial bid.

As argued above, ${ }^{51}$ treasury purchases reduce the recipient's reservation price. If the treasury share agreement is so extreme that the recipient's reservation price is reduced below its initial offer $\left(B_{I}{ }^{I}>\right.$ $\left.B_{I}^{*}\right)$, then higher-valuing third parties may be foreclosed. Extreme forms of treasury sales cause the bidder purchasing treasury shares to root for rivals to outbid its initial offer. As depicted in Figure 3, when

Smith v. Pritzker, No. 6342, 1982 WL 8774, 14-15 (Del. Ch. July 6, 1982), rev'd sub nom. Smith v. Van Gorkom, 488 A.2d 858 (Del. 1985).

49. Overinsuring treasury sales can be negotiated through two analytically distinct scenarios. Under one scenario, a bidder proposes an initial bid and the target proposes a treasury sale to buy "time" to hold a takeover auction. This scenario parallels the facts of Van Gorkom, see Van Gorkom, 488 A.2d at 866-68. Overinsurance results from this process if, given the initial offer, the treasury sale unduly reduces the bidder's reservation price.

Under an alternative scenario, however, the target management conditions the treasury sale upon receiving a higher initial bid. Overinsurance results from this process if the induced higher initial bid is greater than the bidder's reservation price. While both types of negotiation foreclose higher-valuing bidders, treasury sales that induce higher initial bids might benefit target shareholders and thus rebut allegations of fiduciary breach. See infra note 72 .

While these processes for negotiating treasury sales are analytically distinct, they may be difficult to distinguish in practice. In some situations, target management may sell treasury shares to buy both "time" and "a higher initial bid." Moreover, if courts subject treasury sales that induce higher bids to less scrutiny, then both bidders and targets may enter into sham negotiations. For example, in anticipation of litigation, Pritzker might offer an unfaithful Trans Union management a sham initial bid at a low, nonforeclosing price, say $\$ 40$, followed by negotiations resulting in a higher initial bid of $\$ 55$ nominally made in exchange for the treasury share option.

Because of these difficulties, courts should initially focus on the degree, rather than the form, of foreclosure. As argued below, see infra note 72, plaintiffs should at least be able to establish a prima facie case of target mismanagement by evidence of overinsurance.

50. See supra text accompanying note 16 .

51. See supra notes $14-21$ and accompanying text. 
FIgURE 3: ForecLosure

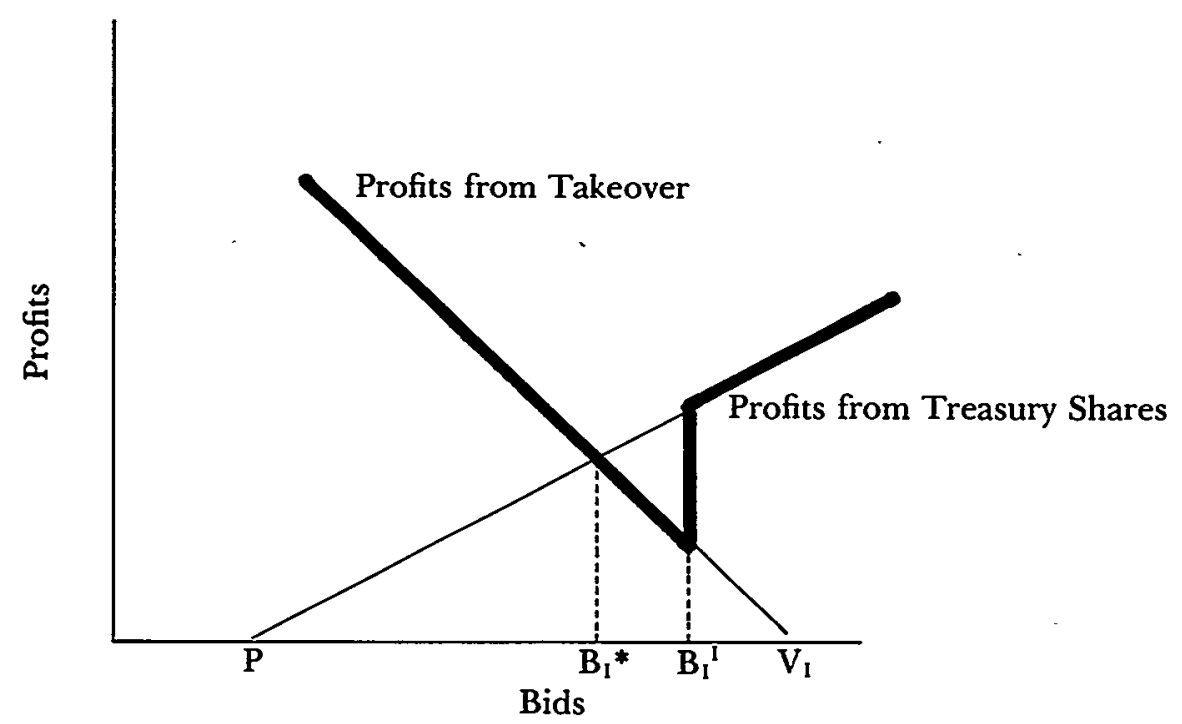

$B_{1}{ }^{l}$ is to the right of $B_{1}^{*}$, there is a discontinuity at the initial bid price, $B_{I}^{I}$, between the profits from winning and losing a takeover auction. If a third-party bidder matches the initial bid, the recipient of treasury shares would gain more by tendering its shares than by completing its own tender offer. A bidder purchasing the treasury shares under these conditions would not be willing to match a competing bid that was even slightly higher than the initial bid. Indeed, if it could retain its treasury shares, it would prefer to lower its outstanding offer and invite rivals to outbid it.

The earlier analysis showed that initial and third-party bidders would have identical costs in raising their bids, because the "opportunity" cost of treasury sales for initial bidders was identical to the "diluting" cost for third-party bidders. ${ }^{52}$ But when target companies insure more than $100 \%$ of an initial bidder's takeover risk, foreclosure stems from the unwillingness of third parties to match the initial offer. As before, the bidders with identical valuations $\left(V_{1}\right.$ and $\left.V_{3}\right)$ will have identical incentives to raise a given bid. But the target corporation can condition the sale of treasury shares on higher initial bids: the target can use the gnarantee of treasury profits to induce the initial bidder to make a higher initial tender offer. ${ }^{53}$

53. From Figure 3, we know that given the treasury sale, the initial bidder would 
It is possible to show algebraically that third parties may be foreclosed from bidding when the initial offer is above a bidder's reservation price. From equation (8), we know that a third party's maximum bid after a treasury sale equals:

$$
B_{3}^{*}=\left(N V_{3}+P T\right) /(N+T) \text {. }
$$

A third party will be able to enter a competing bid only if its maximum bid, $B_{3}{ }^{*}$, is greater tban or equal to the treasury share recipient's initial bid, $B_{I}{ }^{I}\left(B_{3}^{*} \geq B_{I}{ }^{I}\right)$. Setting $B_{3}^{*}$ equal to the initial bid $B_{I}{ }^{I}$ and solving for $V_{3}$, we can derive $V_{3}{ }^{\text {min }}$, the minimum valuation that third-party bidders must have to match the initial bid (after the effects of treasury share diluting):

$$
\begin{aligned}
& B_{1}{ }^{l}=\left(N V_{3}+P T\right) /(N+T) . \\
& \text { (10) } V_{3}^{\min }=\left[B_{1}^{l}(N+T)-P T\right] / N .
\end{aligned}
$$

By substituting for $B_{I}^{*}$ from equation (3), ${ }^{54}$ this equation can be simplified to:

$$
\text { (11) } V_{3}^{\min }=V_{1}+\left(B_{1}{ }^{1}-B_{1}^{*}\right)(N+T) / N \text {. }
$$

The minimum valuation that a third party must have to match the initial bid will exceed $V_{I}$ by a discreet amount whenever $B_{I}{ }^{I}>B_{I}^{*}$. By increasing the amount of overinsurance, a target can arbitrarily set the amount by which the initial bid exceeds the initial bidder's reservation price $\left(B_{1}^{1}-B_{I}^{*}\right)$. Accordingly, overinsurance can arbitrarily increase the minimum valuations for third party matching bids $\left(V_{3}{ }^{\text {min }}\right)$ above the initial bidder's valuation $\left(V_{I}\right)$.

Equation (11) shows how overinsurance can foreclose higher-valuing third-party bidders: With a treasury sale that overinsures (so that $\left.B_{I}^{I}>B_{I}^{*}\right)$, some third parties who valued the firm more than the initial bidder nonetheless will fail to match the initial bid $\left(V_{3}^{\min }>V_{3}>V_{1}\right)$.

like to lower its opening bid. However, because the treasury sale is conditioned upon this initial high bid, the initial bidder is not asked whether it would still like to match its initial bid; only third parties have the choice, given the treasury sale, of whether or not to match. Overinsurance thus forecloses third-party participation in the auction from the outset by discouraging them from matcbing the initial bids of treasury share recipients. An implication of this analysis is that treasury sale agreements that do not discourage competing offers probably insure less than $100 \%$ of the initial takeover risk and accordingly are nonforeclosing: One matching third-party bid powerfully refutes the notion of foreclosure.

54. Adding and subtracting $B_{1}$ to the right-hand side of equation (10) yields:

$$
\begin{aligned}
V_{3}^{m m} & =\left[\left\{B_{I}{ }^{\prime}-B_{I}^{*}+B_{I}^{*}\right\}(N+T)-P T\right] / N . \\
& =\left[\left\{\left(B_{I}{ }^{\prime}-B_{I}^{*}\right)+B_{I}^{*}\right\}(N+T)-P T\right] / N \\
& =\left[\left\{\left(B_{I}{ }^{\prime}-B_{I}^{*}\right)(N+T)\right] / N+\left[B_{I}^{*}(N+T)-P T\right] / N .\right.
\end{aligned}
$$

Substituting the equivalent expression for $B_{I}$ from equation (3) yields:

$$
\begin{aligned}
& =\left[\left(B_{I}{ }^{l}-B_{l}^{*}\right)(N+T)\right] / N+\left[\left\{\left(V_{l} N+P T\right) /(N+T)\right\}(N+T)-P T\right] / N \\
& =\left[\left(B_{l}{ }^{I}-B_{l}^{*}\right)(N+T)\right] / N+V_{l} .
\end{aligned}
$$


Equation (9) algebraically represents the intuition that treasury sales do not foreclose if the higher-valuing third-party bidders prevail $\left(V_{3}>V_{1}\right)$. Equation (11), however, demonstrates that when treasury shares overinsure, a range of higher-valuing third parties will lack an incentive to match the initial bid.

The treasury share agreement in Figure 3 provides more than $100 \%$ profit insurance for the initial bid. Rational bidders and faithful management would not contract for this much insurance. Given the treasury sale, the bidder would prefer to reduce its initial bid to $B_{1}{ }^{* 55}$ Faithful target management, negotiating for additional auction time, would not need to guarantee a bidder more than its expected profits from winning a takeover. Overinsuring a bidder's takeover risk, therefore, can be seen as a "give away" by the target management: Faithful managers should be able to buy the extra time needed to create an auction for a smaller price. Target management should be able to elicit a "stalking horse" offer for fewer treasury shares sold at a higher price.

\section{B. Voting Foreclosure as Red Herring}

Some courts have suggested that treasury sales also can create a form of "voting lock-up" if the treasury shares, by themselves, significantly affect the recipient's chance of obtaining voting control of the target corporation.56 For example, if Trans Union's management had sold Pritzker 13 million treasury shares, Pritzker would have had a majority voting interest without even tendering for additional shares. Such an extreme treasury sale would guarantee the recipient the option of taking over the target because voting control would be a fait accompli.

It is difficult to demonstrate, however, why such voting lock-up would increase the foreclosing effect of overinsurance. If there is no foreclosure, obtaining a voting majority should not affect a bidder's behavior. For example, if Trans Union sold Pritzker 13 million treasury shares at $\$ 60$ per share, there would be no overinsurance foreclosure, ${ }^{57}$

55. A rational bidder would prefer to bid $B_{l}^{*}$ because it would realize a higher profit regardless of whether it won the auction at that price or tendered its treasury shares to a higher-valuing third-party bidder. Graphically, this is shown in Figure 3 because the equilibrium profit line with $B_{l}^{\prime}=B_{l}^{*}$ is everywhere greater than or equal to the equilibrium profit line with $B_{l}^{l}>B_{l}^{*}$.

56. In reviewing the Pritzker/Trans Union treasury sale agreement, the Delaware chancery court concluded that the transaction "did not affect the vote of the stockholders which approved such merger, or stand in the way of possible bids by other interested parties." Smith v. Pritzker, No. 6342, I982 WL 8774, 23 (Del. Ch. July 6, 1982), rev'd sub nom. Smith v. Van Gorkom, 488 A.2d 858 (Del. I985). This conclusion explicitly delineates voting and bidding foreclosure.

57. Purchasing the treasury shares at $\$ 60$ per share (Pritzker's own valuation of the target, $V_{l}=\$ 60$ ) ensures that there is no overinsurance because Pritzker will profit more from winning the takeover than from tendering his treasury shares to a matching bid. Purchasing the treasury shares at $\$ 60$ per share ensures that there is no "diluting" effect of the synergistic value. 
but Pritzker would have voting control of Trans Union and therefore would be able to force a takeover. Yet Pritzker would have no reason to block third-parties that made higher bids from taking over the firm because he then could tender his treasury shares to these third parties at a price greater than their value to him. ${ }^{58}$ As long as higher-valuing third parties have higher reservation prices, the percentage of outstanding shares that a treasury share recipient controls, by itself, should not have a foreclosing effect. In assessing the foreclosing effects of treasury share agreements, courts should restrict their attention accordingly to instances of overinsurance. ${ }^{59}$

\section{A Proposed Legal Standard for Adjudicating the Validity of Treasury Share Agreements}

When treasury sales provide extreme forms of overinsurance, courts should reach the conclusion that the primary purpose of the sale was to foreclose third-party bidders, and thus that the target management has breached its fiduciary duties to its shareholders. In the extreme, courts should invalidate agreements in which they determine that the treasury shares provide more than $100 \%$ insurance. ${ }^{60}$ To apply this standard, courts need to consider whether the treasury share recipient would profit more from tendering its treasury shares to a hypothetical bid that matched the initial offer than from a takeover at the initial offer. It is a straightforward matter to calculate the profits of tendering the treasury shares $\left[\left(B_{l}^{l}-P\right) T\right]$. The court then should assess whether the treasury share recipient could have hoped to earn more from the takeover. Because the profits from winning the takeover $\left[\left(V_{l}-B_{l}^{l}\right) N\right]$ are necessarily a function of the bidder's valuation, courts would need to estimate the initial bidder's per share valuation. Courts of course cannot do this with precision. However, the more that the treasury sale foreclose potential rivals, the more inflated will be the

58. This again assumes, see supra note 42 , that Pritzker cannot costlessly resell the target to a higher-valuing third party. If such resale were possible, Pritzker might prefer to block the third-party bid and force a back-end merger so that he could profit from reselling minority shares at a higher price.

59. To the extent that "voting lock-up" remains a judicial concern, courts should prefer agreements with larger discounts but fewer shares. Since the amount of takeover insurance is a function of the number of treasury shares and their price, see supra note 16 and accompanying text, target management can offer equivalent amounts of takeover insurance by lowering either the number or price of treasury shares. For example, 10 million shares at $\$ 38$ per share provides the same amount of initial bid insurance [ $\$ 55$ $-\$ 38)$ I0 million $=\$ 170$ million] as 5 million treasury shares at $\$ 21$ per share [ $\$ 55-$ $\$ 2$ I) 5 million $=\$ 170$ million]. The latter agreement is less likely to cause "voting lockup" because the treasury share recipient acquires a smaller percentage of the target's outstanding shares.

60. Judicial invalidations could take the form of I) enjoining the planned treasury sales, 2) ordering rescission of executed sales, or 3) holding target management liable for breaches of its fiduciary duty. The proper scope of a judicial remedy would turn primarily on whether the treasury sale or merger was completed. 
requisite bidder valuation. In extreme cases, a court should be able to confidently determine that foreclosure has resulted because the requisite bidder valuation will be beyond the reasonable range of possible valuations.

For example, returning to the facts of the Trans Union takeover, the court should have asked itself whether Pritzker would have tendered his treasury shares to a rival who matched his initial bid. It is easy to calculate that Pritzker's profits from tendering to the rival would have been $\$ 17$ million $\left[\left(B_{I}^{I}-P\right) T\right]$. The court then should have assessed whether Pritzker conceivably could have profited as much from taking over Trans Union at his initial bid. From equation (1), the profits from winning a takeover are:

$$
\left(V_{1}-B_{1}\right) N \text {. }
$$

For these profits to be greater than $\$ 17$ million implies that Pritzker's per share valuation was:

$$
\begin{aligned}
& \left(V_{1}-\$ 55\right) 13 \text { million } \$ 17 \text { million } \\
& V_{l}>\$ 56.30 .
\end{aligned}
$$

Under this analysis, the Trans Union treasury sale seems to have been well within reason. ${ }^{61}$ It does not stretch the imagination to conceive that Pritzker valued the firm this much. Trans Union itself estimated the share value to be between $\$ 55$ and $\$ 65.62$ Without more, a court should not enjoin the Pritzker treasury sale for having a foreclosing or lockup effect. ${ }^{63}$

61. The Delaware chancery court reached this same conclusion for different reasons. Smith v. Pritzker, No. 6342, 1982 WL 8774, 6-7 (Del. Ch. July 6, 1982), rev'd sub nom. Smith v. Van Gorkom, 488 A.2d 858 (Del. 1985). The chancellor summarily dismissed the lock-up allegation:

[The] transaction, I believe, did not affect the vote of the stockholders which approved such merger, or stand in the way of possible bids by other interested parties. Thus, while a competing bidder would be required to pay $\$ 17$ million more than the Pritzker's offer to equal such offer ( $\$ 55$ less $\$ 38$ times one million shares equals $\$ 17$ million), this is a modest amount in the context of a $\$ 690$ million transaction. And while plaintiffs rely on Mobil Corp. v. Marathon Oil Co., [669 F.2d 366 (6th Cir. 1981)] a case which was involved with offers for tenders of stock of Marathon Oil Co. in a case involving competing bids by Mobil and others in which the United States Steel Co. had acquired an option to purchase $10,000,000$ authorized but unissued shares of Marathon for $\$ 90.00$ a share at a time when there were 58,685,906 Marathon common shares outstanding, the Court stated: "In our opinion, the stock option was large enough in this takeover contest to serve as an artificial and significant deterrent to competitive bidding for a controlling block of Marathon shares." I do not for the reasons stated believe that such case is controlling here.

Id.

62. Smith v. Van Gorkom, 488 A.2d 858, 867 (Del. 1985) (Trans Union's chief financial officer's estimate of firm's value for purposes of a leveraged buyout).

63. Indeed, the Delaware Supreme Court appeared to base its decision to impose liability on the Trans Union directors upon the ancillary aspects of the treasury agree- 
Yet, the foregoing analysis also indicates that the "foreclosure" or "overinsurance" standard articulated above will give target management a large amount of discretion to issue treasury shares to bidders. For example, if Trans Union had sold not 1 but 10 million treasury shares, Pritzker would need to value the firm at a minimum of $\$ 68$ per share to make the takeover profits larger than the profits from tendering. ${ }^{64}$ It is possible, however, that selling Pritzker even 10 times the number of treasury shares would not have caused foreclosure. ${ }^{65}$ A natural question, then, is whether less extreme forms of treasury sales should be invalidated even if they do not cause foreclosure, i.e., even if they do not foreclose higher-valuing third parties from taking over the target. The hard question is whether courts should invalidate agreements in which treasury shares provide less than $100 \%$ auction insurance.

To answer this question, we must first remember that even in the absence of foreclosure, target shareholders may still be injured by treasury sales. The profitability for target shareholders turns, inter alia, on the degree to which treasury shares induce higher competitive offers. ${ }^{66}$ If higher bids are not anticipated, then even treasury sales that do not cause foreclosure may precipitate an auction with a lower winning bid. A treasury sale will affect third-party bids both through an "auctioncreation effect" and through a "diluting effect." The former increases the likelihood of third-party bids being made, but the latter lowers the maximum amount that third parties will bid. Even a nonforeclosing treasury sale will harm target shareholders if the diluting effect exceeds the effect of creating an auction.

Consequently, courts might go beyond the prohibition of foreclosure to set aside treasury sales that are not cost justified. Under this standard, courts would assess whether the target's auction-insurance cost was proportional to the benefits of auction creation. Indeed, the Delaware chancery court recently adopted a similar standard. The court held that " $[\mathrm{i}] \mathrm{t}$ is not necessarily inconsistent . . . for directors to

ment, such as the no-shop clause, rather than on the amount of overinsurance involved. See id. at 878-85.

64. If Pritzker had bought 10 million treasury shares $(T=10$ million), then for the takeover profits to be greater than the tendering profits:

$\left[\left(B_{I}{ }^{\prime}-P\right) T\right]<\left(V_{l}-B_{I}{ }^{\prime}\right) N$

[(\$55 - \$38) I0 million] $<\left(V_{t}-\$ 55\right) 13$ million

$\$ 170$ million $<(V) 13$ million $-\$ 715$ million

$\$ 885$ million $<\left(V_{l}\right) 13$ million

$V_{I}>\$ 68.08$.

65 . Under the analysis presented in the previous section, see supra notes $48-55$ and accompanying text, a court should determine that such an agreement caused foreclosure if it found that Pritzker valued Trans Union at less than $\$ 68$ per share.

66. See supra notes $38-46$ and accompanying text (discussing the possibility of facilitating an auction through the sale of treasury shares). 
grant lock-up options (for stock or assets) or agree to no-shop clauses. ... Where there are competing bidders, and the company's directors do not treat all of the bidders equally, 'the board's action must be reasonable in relation to the advantage sought to be achieved." "67 Although the Delaware courts have applied a similar "proportionality" standard to defensive tactics that might entrench incumbent target management, ${ }^{68}$ this standard is less appropriate for analyzing the effects of stock lock-ups. Target managers do not have a conflict of interest in making such imprudent, but nonforeclosing, treasury agreements because such agreements will not prevent a higher-valuing third party from outbidding the treasury share recipient. ${ }^{69}$ If higher-valuing third parties are not foreclosed from the auction, imprudent treasury sales will only affect the size of the winning bid, not the winner's identity. Imprudent, but nonforeclosing, treasury agreements accordingly are poor methods for entrenching incumbent target managers. ${ }^{70}$ The absence of this competing managerial interest militates in favor of the less stringent scrutiny that is generally applied to managerial decisions-the business judgment rule. ${ }^{71}$ Thus, courts should enjoin only treasury sales that insure more than $100 \%$ of a bidder's takeover bid. The term "lock-up" only is appropriate for the more extreme treasury sales which foreclose competitive bids, because only these agreements truly discourage higher-valuing bidders from raising the initial bidder's ante. $^{72}$

67. Rand v. Western Airlines, Inc., [Current] Fed. Sec. L. Rep. (CCH) ๆ 94,751, at 94,053 (Del. Ch. 1989) (emphasis added) (quoting Mills Acquisition Co. v. Macmillan, Inc., 559 A.2d 1261, 1288 (Del. 1988)). Indeed, it is arguable that Rand establishes an even more stringent test of management fidelity. The opinion suggests: "If the grant of an auction-ending provision is appropriate, it must confer a substantial benefit upon the stockholders in order to withstand exacting scrutiny by the courts.'. . Only after satisfying this standard will the directors' actions be accorded the protection of the business judgment rule." 1d. (emphasis added) (quoting Macmillan, 559 A.2d at 1284).

68. See Unocal Corp. v. Mesa Petroleum Co., 493 A.2d 946, 955 (Del. 1985) (defensive tactics must be "reasonable in relation to the threat posed" by a hostile offer); Gilson \& Kraakman, Delaware's Intermediate Standard for Defensive Tactics: Is There Substance to Proportionality Review?, 44 Bus. Law. 247, 252-60 (1989).

69. See supra pp. 694-95.

70. It may be that in an uncertain world even treasury sales that insure less than $100 \%$ of an initial bidder's risk will nevertheless dissuade third-party bids. Unfaithful target managers, playing upon such uncertainty, might still have a conflict of interest in negotiating the treasury sale. Even if a treasury sale is nonforeclosing, target management should be held liable if it enters into such a sale (mistakenly) thinking that it will foreclose rival bidders. Even though rivals are not foreclosed, target shareholders are likely to be damaged by the treasury sale, because the resulting auctions will be won at a lower bid.

71. The business judgement rule is "a presumption that in making a business decision the directors of a corporation acted on an informed basis, in good faith and in the honest belief that the action taken was in the best interests of the company." Aronson v. Lewis, 473 A.2d 805, 812 (Del. 1984). See generally R. Clark, supra note 3, § 3.4 (discussing tensions between business judgment rule and duty of care).

72. As the earlier example indicated, an overinsurance or foreclosure standard 
Courts, however, might look to ancillary aspects of the treasury sale in determining whether the sale is in the target stockholder's best interest. Particularly, courts might examine any information restrictions placed on the target. If the treasury sale is negotiated in order to create an auction for the target, then the treasury sale agreement should allow the target to disclose the same information to third-party bidders that has been disclosed to the initial bidder. This especially is true because, as discussed above, ${ }^{73}$ an important source of the mutual gains from entering into such agreements comes from locating highervaluing third-party bidders. Indeed, if the treasury sale is driven by the joint desire of the initial bidder and the target corporation to elicit a bid greater than $V_{l}$, then one would expect that the initial bidder itself would become a ready and willing conduit of information about the target to potential third-party bidders. A treasury share sale can turn the treasury share purchaser into a sales agent of the target corporation. This suggests that the more serious charges leveled against the Trans Union treasury agreement may have concerned the informational restrictions that could have undermined the ensuing auction. ${ }^{\mathbf{7 4}}$ If target management is to defend its behavior by claiming it was bar-

gives target management great leeway in negotiating "large" treasury sales. See supra notes $64-65$ and accompanying text. It is possible, however, to say that courts should be even more lenient. While overinsurance can be caused by "give aways" from an unfaithful target management (such as an increase in the number of treasury shares or a decrease in their price), it is also possible that overinsurance stems from a faithful management negotiating, inter alia, a higher initial bid. See supra note 49 . For example, if Trans Union had conditioned Pritzker's treasury sale on a requirement that Pritzker begin the bidding at $\$ 59$ per share, then under our earlier assumptions, see supra text accompanying notes 25-26, the treasury sale would have a foreclosing effect (because $\$ 59=B_{I}^{\prime}>B_{I}^{*}=\$ 58.43$ ). This suggests that a foreclosing treasury sale may be engineered by either faithful or unfaithful management. Indeed, a perverse effect of an overinsurance standard is that target management could protect itself from charges of infidelity for any size treasury sale simply by negotiating a lower initial bid for its shareholders.

While the liability implications of an overinsurance standard appear harsh when management has elicited a higher initial bid, these higher bids come at the cost of foreclosing even higher-valuing bidders. Given the great discretion that target management enjoys under an overinsurance standard, at a minimum courts should shift the burden to the target to justify the size of the treasury sale in relation to any enhanced negotiated initial bid and anticipated higher bids. The target management could then rebut a presumption of fiduciary breach by showing either that the treasury sale was conditioned upon a higher initial bid, or that they were not grossly negligent in believing that the treasury sale was not foreclosing. Cf. Smith v. Van Gorkom, 488 A.2d 858, 873 (Del. 1985) (issue of whether directors have breached their duty of care determined under gross negligence standard (citing Aronson v. Lewis, 473 A.2d 805, 812 (Del. 1984))).

73. See supra notes $38-46$ and accompanying text (discussing increased probability of finding higher-valuing bidders resulting from treasury share sale).

74. Van Gorkom conceded that "the Agreement barred Trans Union from actively soliciting [competing] offers and from furnishing to interested parties any information about the Company other than that already in the public domain." Smith v. Van Gorkom, 488 A.2d 858, 878 (Del. 1985). 
gaining to create an auction, the ancillary provisions of the agreement should be consistent with such a motivation. ${ }^{75}$

\section{Limiting the Target Corporation's Ability to "Contract Around" This Standard: Single-Sided Immutability}

This proposed legal standard represents a kind of single-sided immutable rule. Corporate rules can be divided into two classes: one class of rules are merely "defaults" which govern in the absence of a countervailing charter or bylaw provision, while a second class of rules are "immutable" and cannot be changed through corporate action. ${ }^{76}$ The proposed standard for scrutinizing treasury sales would be "singlesided" in the sense that target corporations could enact bylaws or charter provisions that further restricted the ability of their managers to enter into these agreements, but target corporations would not be allowed to execute corporate provisions which increased the ability of target management to make overinsuring "lock-up" treasury sales. Target corporations could, in a sense, contract around the proposed default for more judicial scrutiny, but could not contract for less scrutiny.

The rationale for this partial restriction of corporate freedom of contract is that rational shareholders might wish to further restrict treasury sales, ${ }^{77}$ but would not want to allow their managers to enter into treasury stock agreements that would foreclose subsequent auctions. Rational shareholders would not want to foreclose higher-valuing bidders from an auction.

The immutable aspect of the rule is similar to the immutable requirement of "good faith" in the law of contracts. Both the common law and the Uniform Commercial Code impose an immutable obligation of good faith in the performance of every contract. ${ }^{78}$ Even if parties enter into an agreement waiving one side's obligation of good faith, courts will not enforce the provision. Because no rational person would contract to let the other side act in bad faith, the courts assume

75. This analysis also suggests that the sale of treasury shares should estop target management from arguing that a takeover auction is not in its shareholders' best interests. Under Delaware law, when a takeover becomes "inevitable," target management has an affirmative obligation to obtain the highest possible bid. Revlon, Inc. v. MacAndrews \& Forbes Holdings, 506 A.2d 173, 182 (Del. 1986). The sale of treasury shares to an active bidder should trigger this affirmative duty to conduct a takeover auction.

76. See Ayres \& Gertner, supra note 10, at 87-95.

77. As stressed above, see supra note 66 and accompanying text, nonforeclosing treasury sales still may injure target shareholders if the "diluting" effect is greater than the "auction-creation" effect. Target shareholders seeking to induce initial bids, therefore, rationally may want to precommit themselves to a policy forbidding treasury sales.

78. See Restatement (Second) of Contracts $\S 205$ \& comment d (1981); U.C.C. $\S 1$ 203 (1989). See generally E. Farnsworth, Contracts $\S 7.17$ \& n.3 (1982) (discussing sources and nature of good-faith requirement). 
that there could not have been true assent to such terms; there must have been a failure in the process of contracting. Similarly, if courts find corporate charter provisions of a target attempting to legitimate a stock lock-up that rational target shareholders would not favor, then courts should assume a failure of corporate governance-that target management must not have faithfully pursued the objective of maximizing shareholder value.

Such single-sided immutable rules already exist in both the law of contracts and corporations. For example, contracts law permits covenants not to compete covering a reasonable period of time but prohibits covenants that extend beyond reasonable lengths. ${ }^{79}$ Similarly, corporations can contract with employees to go beyond the federal insider trading prohibitions, but cannot contract to abrogate or reduce the insider trading standard. ${ }^{80}$ Thus, while the "overinsurance" standard effectively grants target management great discretion in negotiating treasury sales, the management should not be able to. amend its bylaws or articles of incorporation to "contract" for even more discretion.

\section{Additional Applications}

\section{A. The Greenmail Alternative}

The foregoing analysis of target treasury sales can also inform courts' analysis of "greenmail." Greenmail is a defensive tactic in which target management buys back, at a premium, shares acquired by an initial bidder. ${ }^{81}$ Professors Jon Macey and Fred McChesney have argued that "greenmail payments can actually improve the price shareholders receive in tender offers by facilitating an auction market for a firm's stock." 82

Selling treasury shares to an initial bidder has virtually all the economic attributes of greenmail. Like greenmail, a treasury sale to an initial bidder eliminates the third-party bidder free-rider problem by compensating the initial bidder for any informational investment. ${ }^{83}$ Like greenmail, a treasury sale does not waste real resources, but

79. See E. Farnsworth, supra note $78, \S 5.3 \&$ n.6.

80. See 15 U.S.C. $\$ 77 t(1)$ (a) (1988). The statute does not, however, explicitly say that private parties may not waive its provision. See Jordan v. Duff \& Phelps, Inc., 815 F.2d 429, 437 (7th Cir. 1987) (Easterbrook, J.) (dicta that even insider trading prohibitions are merely default rules which corporate employment contracts could negate).

81. See R. Clark, supra note $3, \S 13.6$, at 574 .

82. Macey \& McChesney, supra note 12 , at 15 .

83. If third parties are able to reduce their costs of participating in an auction because of the investigative investments previously made by the first party, the third-party bidders are "free riding" on the initial bidder's investments. See R. Posner, Economic Analysis of Law $\S 3.7$, at 55 (3d ed. 1986) (defining "free riding"). If the initial bidder is not compensated for its initial investment, it will be less likely to undertake this investment because of the enhanced probability that free-riding bidders will win the auction. Macey and McChesney point out that greenmail, unlike other defensive tactics, "actually 
merely represents a transfer from the target to the initial bidder. ${ }^{84}$ Like greenmail, a treasury sale lowers the reservation price of subsequent third-party bidders, but allows such bidders more time to formulate and finance their bid. In sum, a treasury sale, like a greenmail purchase, can facilitate a takeover auction for a target corporation. And, as Macey and McChesney stress, treasury sales can create an auction without reducing the initial bidder's ex ante incentives to seek out value enhancing information.

Greenmail purchases differ from treasury share sales, however, in one important way. Greenmail (and standstill) agreements remove the initial bidder from the subsequent auction. Under treasury sale agreements, if no competitive bids are forthcoming, the target shareholders will still reap the benefits of the initial bid $\left(B_{I}{ }^{I}-P\right)$. Under greenmail purchase agreements, however, the target shareholders gain nothing if subsequent bidders do not appear. Indeed, because the initial bidder is bought off with the greenmail premium, the per share value of the remaining outstanding shares should, as a theoretical matter, decrease. Empirical studies dramatically illustrate how target companies' stock prices are decimated when defensive tactics preclude a takeover ${ }^{85} \mathrm{Be}-$ cause a sale of treasury shares accomplishes everything that greenmail does and also increases the probability that target shareholders will ultimately receive a tender offer premium, treasury sales dominate greenmail from a shareholder wealth maximization perspective. The very availability of treasury sales strongly suggests that greenmail is used not to benefit shareholders but to entrench management. Buying back greenmail shares instead of selling treasury shares thus borders on prima facie evidence of target management male fide. ${ }^{86}$ The possibility

solves the free-rider problem" because the initial bidder is paid "at least the expected value to her of the minority takeover." Macey \& McChesney, supra note 12, at 30 .

84. In the case of a treasury sale, the transfer is contingent on the initial bidder's losing the subsequent takeover auction. See supra note 20 and accompanying text. The amount of the transfer is equal to the losing bidder's profits from the treasury shares, $\left(B_{3}\right.$ - P)T. See supra p. 687 (equation (2)) \& pp. 694-95.

Other defensive tactics, like the "scorched earth" technique in which the target threatens, inter alia, to dissipate key assets may consume real resources. See Gurwin, The Scorched Earth Policy, Institutional Investor, June 1979, at 32, 35.

85. See Easterbrook \& Jarrell, Do Targets Gain from Defeating Tender Offers?, 59 N.Y.U. L. Rev. 277, 281-91 (1984); see also Ryngaert, The Effect of Poison Pill Securities on Shareholder Wealth, $20 \mathrm{~J}$. Fin. Econ. 377, 386-408 (1988) (finding that poison pills decrease shareholder wealth). See generally R. Gilson \& R. Kraakman, The Law and Finance of Corporate Acquisitions 133-38 (Supp. 1989) (analyzing studies of poison pill plans).

86. Macey and McChesney point to the fact that in empirical studies of greenmail, for " $44 \%$ of the repurchasing firms, the payment of greenmail was associated with a positive change in shareholder returns." Macey \& McChesney, supra note 12, at 47. This $44 \%$ figure gives support to their argument that in some instances greenmail benefits shareholders. However, there are other reasons that might explain this $44 \%$ figure. If the market was already expecting a greenmail payment, in some proportion of the cases the actual payment would be less than the market expectation. Market reaction, there- 
of target treasury sales undermines the rationale for target treasury purchases.

\section{B. Treasury Sales to White Knights: The Possibility of Efficient Resistance}

In a number of takeover contests, target management has sold treasury shares not to the initial bidder (as in the Trans Union contest), but to a subsequent third-party bidder. ${ }^{87}$ The sale of treasury shares to these white knights (friendly third-party bidders) raises different policy questions for lawmakers regulating the takeover arena. Most importantly, the sale of treasury stock to subsequent bidders promotes free riding on the investments of the initial bidders. White knight treasury sales guarantee the subsequent bidder a profit from the ensuing takeover contest at the expense of the initial bidder's profits. Because white knight treasury sales reduce the incentives of initial bidders to undertake investigations that may produce socially valuable information, some academics argue that courts should prohibit this form of target resistance. For example, Frank Easterbrook and Dan Fischel have argued that courts should enjoin managerial resistance to tender offers because resistance by targets reduces the initial bidder's incentives to search for profitable takeover targets. ${ }^{88}$

The possibility of such ex post free riding, however, can still be ex ante efficient. As David Haddock, Jon Macey, and Fred McChesney have shown, allowing target resistance can promote value-creating investments by prospective targets which might overcome the free-riding effect on initial bidders. ${ }^{89}$ Prospective targets, as well as prospective bidders, have incentives to find the perfect match in a merger. Wealthmaximizing merger law should seek to engender efficient investments in search by the efficient searchers. Their arguments have particular force with regard to treasury share resistance.

Prohibiting white knight treasury shares would significantly undermine the incentives of target managers to seek out higher-valuing third parties-for the simple reason that target shareholders would receive a lower return from such search expenditures. ${ }^{90}$ Treasury sales to white knights also might be necessary to induce value-creating investments by

fore, would be positive because the management waste was not as bad as was expected. See Black, supra note 31, at 613-15.

87. See, e.g., Mobil Corp. v. Marathon Oil Co., 669 F.2d 366, 367 (6th Cir. 1981); Buffalo Forge Co. v. Ogden Corp., 555 F.Supp. 892, 895 (W.D.N.Y. 1983).

88. Easterbrook \& Fischel, Auctions and Sunk Costs in Tender Offers, 35 Stan. L. Rev. 1, 21 (1982); Easterbrook \& Fischel, The Proper Role of a Target's Management in Responding to a Tender Offer, 94 Harv. L. Rev. 1161, 1176-77 (1981).

89. Haddock, Macey \& McChesney, Property Rights in Assets and Resistance to Tender Offers, 73 Va. L. Rev. 701, 709-12 (1987).

90. In some instances, it will be cheaper for the target to search for bidders and estimate the joint value of the corporations. 
the prospective third-party bidders. ${ }^{91}$ Third parties might not invest in research and mount a tender offer without some guaranteed return on their investment. Thus, the use of treasury sales can help induce the entry of competitive bidders into the takeover auction thereby benefiting target shareholders by pushing the bidders toward their reservation prices.

Finally, the possibility of selling treasury shares to third-party bidders can create an ancillary competition for a separate product: time. Treasury share agreements in large part can work to create a takeover auction by buying additional time for interested third parties to investigate, finance and enter competing bids. The target has an interest in buying this time at least cost. If treasury sales to third parties are prohibited, the initial bidder will have an enhanced monopoly in selling this valuable commodity to the target. Under the Williams Act, however, third parties can extend the time of a takeover contest by entering a competing offer. ${ }^{92}$ Promoting competition among bidders to extend the tender offer period affords target managers time to create an auction for their firm at least cost.

Thus, although the possibility of white knight treasury sales reduces the probability of an initial bid, it can increase the returns to target shareholders once the bid has been made. From an ex ante perspective, target shareholders may gain by retaining the ability to enter into such agreements. Moreover, as long as the treasury sale does not foreclose higher-valuing bidders, management entrenchment is not likely to taint the target's motivation. As long as the treasury sale facilitates an auction for the target, the target management is, at worst, imprudent in entering such agreements. Therefore, courts should also enforce treasury sales to white knights under the business judgment rule unless such sales represent a foreclosing overinsurance of the treasury share recipient.

\section{Asset Lock-ups}

Although this Article has focused on the effects of stock lock-ups, its analysis can be applied more broadly to asset lock-ups. For example, in Mobil Corp. v. Marathon Oil Co. ${ }^{93}$ U.S. Steel and Marathon Oil conditioned their merger agreement upon Marathon's giving U.S. Steel "an option to purchase Marathon's 48\% interest in oil and mineral rights in the Yates Field for $\$ 2.8$ billion." 94 If an asset of the target

91. White knight treasury sales give target management a credible way of communicating to prospective third parties that this is a potentially profitable merger.

92. Regulations promulgated under the Williams Act, 15 U.S.C. $\$ 78 \mathrm{n}(\mathrm{d})-(\mathrm{e})$ (1988), extend the period of a tender offer if a bidder increases its offer. 17 C.F.R. $\S 240.14 \mathrm{e}-1$ (b) (1989). A competing offer that forces an initial bidder to raise its bid can thus create extra time for a takeover auction to evolve.

93. 669 F.2d 366, 367 (6th Cir. 1981).

94. Id. The merger agreement was also conditioned on Marathon's granting U.S. 
corporation is optioned to a bidder at a discount, then the asset recipient will have incentives which are analogous to a treasury share recipient. The asset-option recipient will be guaranteed a profit from losing the takeover which will represent an opportunity cost of taking over the firm. The incentives of a bidder with an option to purchase a discounted target asset are depicted in Figure 4.

\section{Figure 4: How Discounted Asset Purchases Affect Bidder Profits}

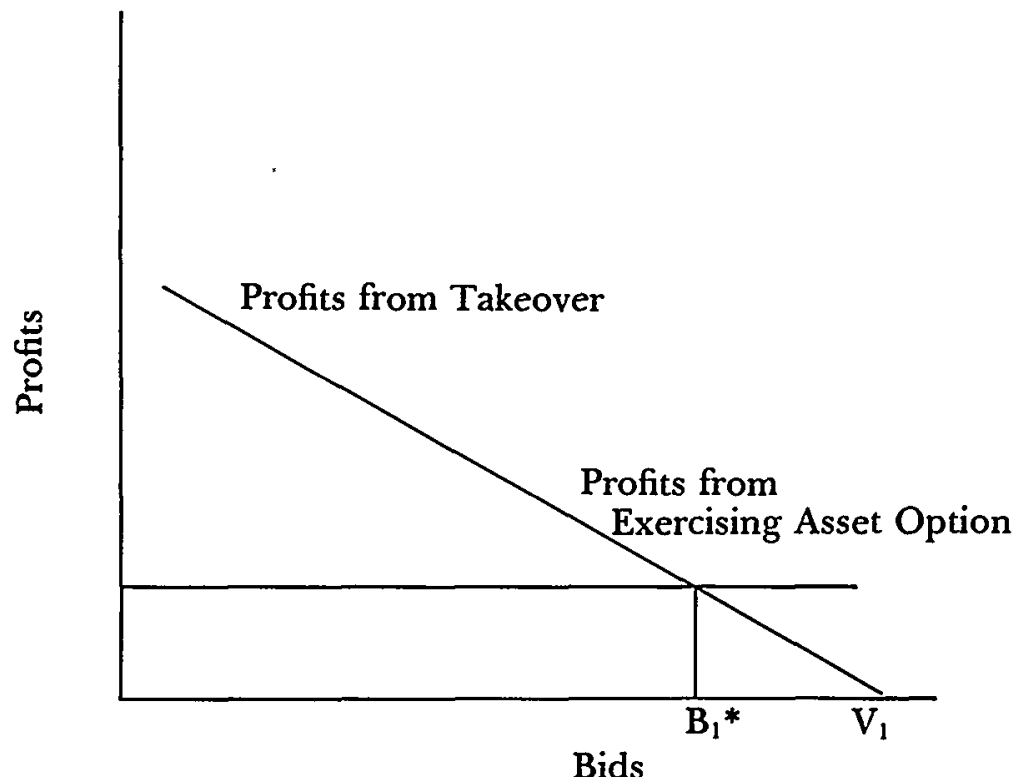

Unlike the treasury share recipient, the profits from losing the takeover are independent of third-party bids. Therefore, while winning the takeover auction entails the opportunity cost of profiting on the asset option, the size of the opportunity cost does not increase as third-party bids increase. This is depicted in Figure 4 by the horizontal profit line for losing the auction contest. As before, the asset option necessarily lowers the recipient bidder's reservation price (from $V_{I}$ to $B_{I}{ }^{*}$ in Figure 4) and, as before, third-party foreclosure is possible if the option recipi-

Steel a stock lock-up, an irrevocable option to purchase ten million authorized but unissued shares of Marathon common stock for $\$ 90$ per share. See supra note 34 , for discussion. The Sixth Circuit struck down the Yates Field option as an asset lock-up: "The only effect of this option can be to deter Mobil and any other potential tender offerors from competing with USS in an auction for control of Marathon." Id. at 375. 
ent can profit more from losing the takeover auction (and exercising the asset option) than from completing the takeover at its initial bid.

\section{CONCLUSION}

The defensive tactic of selling treasury shares to a tender offeror has earned the pejorative sobriquet of "stock lock-up." This Article has shown, however, that for a broad range of treasury sales this terminology is inappropriate. Treasury sales need not foreclose higher-valuing bidders from taking over target corporations. Courts have focused on how treasury sales make it more costly for third parties to bid for the target, but have failed to appreciate how treasury shares affect the recipient's bidding incentives. A bidder purchasing treasury stock bears an opportunity cost in matching its rivals' bids. A bidder can only profit from its treasury shares if it loses the auction and tenders to a rival bidder. Selling a bidder treasury shares lowers the maximum amount third parties will offer, but it also reduces the maximum amount that the recipient of the treasury stock will offer. At some point, the recipient will prefer the increasing profits of dropping out of the auction to the decreasing profits of matching higher bids. Because the reservation price of all bidders is equally reduced, treasury sales need not foreclose third-party bidders.

Treasury sales may benefit target shareholders by expanding the opportunities for third parties to participate in a takeover auction. Although the sale of treasury stock reduces bidders' reservation price for the target shares, an auction with reduced reservation prices may' produce a higher tender offer for target shareholders than no auction at all. Target management may faithfully further its shareholders' interests by entering into such agreements.

This Article, however, has identified an extreme form of treasury sale that can foreclose higher-valuing bidders. The recipients of treasury stock receive a form of takeover insurance that guarantees them a profit even if they lose the ensuing auction. If target management offers to insure more than $100 \%$ of this takeover risk, then courts should invalidate the sale as a breach of the target managers' fiduciary duty. In making this assessment, courts simply should ask whether the recipient of the treasury shares could hope to profit as much from winning the takeover as from losing (and tendering its treasury shares). Overinsurance forecloses rival bidders and should be enjoined. This provides a powerful and straight-forward standard for distinguishing between treasury sales that foreclose rivals to entrench target management and treasury sales that facilitate takeover auctions to maximize shareholder value. 


\section{APPENDIX-Two-Tiered OfFERS}

The analysis of the Article can be applied to takeover contests with competing two-tiered offers. ${ }^{1}$ Understanding the impact of treasury sales in the context of two-tiered offers is of practical importance because the bids in many takeover contests are structured in two tiers. ${ }^{2}$ Consider an initial and a third-party bidder that are considering making two-tiered bids on a particular target. As before, let:

$N=$ number of original outstanding target shares;

$T=$ number of treasury shares sold to initial bidder; and

$P=$ pre-tender stock price and price of treasury shares.

While the second tier bid is less than the first tier bid, the "appraisal rights" of the target corporation minority shareholders constrain the second-tier price from falling below a certain level. For simplicity, assume that the second-tier bid must be at least the pretender offer stock price, $P{ }^{3}$ Profit-maximizing bidders will always buy the second half of the shares at the minimum price, $P$. Reducing the second-tier price puts target shareholders in a prisoner's dilemma because they face the prospect of receiving the inferior second-tier price for their stock if they fail to tender it as part of the first-tier offer. ${ }^{4}$ This prisoner's dilemma powerfully encourages shareholders to tender their shares, for fear of receiving the lower second-tier price. Rational target shareholders would tender their shares to the two-tier bid with the highest average or "blend" price. 5

A treasury sale will affect both the size and price of the first-tier bid. In the absence of a treasury sale, rational bidders will bid for just slightly more than $50 \%$ of the target company shares, $N / 2$, for the front end or first tier of its bid. After a treasury sale of $T$ shares to an initial bidder, however, the amounts needed to gain a majority change. After

1. In a two-tiered offer, a bidder acquires a majority of the target shares at a premium price (the "front-end") and subsequently forces the minority shareholder to sell their remaining shares at a lower price (the "back-end"). See Barron's Dictionary of Finance and Investment Terms 449 (2d ed. 1987) (definition of two-tier bid).

2. See, e.g., Mobil Corp. v. Marathon Oil Co., 669 F.2d 366, 377 (6th Cir. 1981).

3. This assumption accords with case law that minority shareholders are not assured merger profits as part of a takeover. See, e.g., Weinberger v. UOP, Inc., 457 A.2d 701, 713-14 (Del. 1983) (estimates of future value based upon speculative projections "relating to the completion of a merger" may not be included in the court's appraisal; minority shareholders may realize only future value that is "susceptible of proof"); see also Revised Model Bus. Corp. Act $\S \S 13.01(3), 13.30$ (1985) (dissenting shareholders entitled to receive "fair value" for their shares, defined as the pre-merger value of the shares exclusive of any appreciation "in anticipation" of the merger).

4. Macey \& McChesney, A Theoretical Analysis of Corporate Greenmail, 95 Yale L.J. 13, 20-21 (1985); Brudney \& Chirelstein, Fair Shares in Corporate Mergers and Takeovers, 88 Harv. L. Rev. 297, 337 (1974).

5. See Macey \& McChesney, supra note 4 , at 21 . As discussed below, there may be situations in which a bid with a higher first tier bid may have a lower blend price. 
the treasury sale there are $N+T$ shares outstanding. The firm acquiring $T$ shares via the treasury sale only needs to acquire $(N-T) / 2$ shares to gain a majority, ${ }^{6}$ while third-party bidders must bid for $(N+$ $T) / 2$ target shares to gain control in a front end bid. Thus, a treasury sale increases the number of front-end shares for which third parties must bid, and reduces the number for which the treasury share purchaser must bid. To summarize, the treasury share purchaser will attempt to acquire the $N+T$ target shares (after a treasury sale) in the following manner:

\begin{tabular}{cc} 
Number of Shares & $\frac{\text { Source }}{\text { treasury sale }}$ \\
\cline { 1 - 1 } & first tier \\
$(N-T) / 2$ & second tier \\
$(N+T) / 2$ & $B_{1}{ }^{1}=$ the initial bidder's first-tier price, and \\
where $B_{1}{ }^{2}=$ the initial bidder's second-tier price.
\end{tabular}

A third-party bidder will attempt to acquire the $N+T$ target shares (after a treasury sale) in the following manner:

\begin{tabular}{clll} 
Number of Shares & & Source & Price \\
\cline { 1 - 1 }$(N+T) / 2$ & first tier & $B_{3}{ }^{1}$ \\
$(N+T) / 2$ & second tier & $B_{3}{ }^{2}=P$
\end{tabular}

where $B_{3}{ }^{l}=$ the third party's first tier price, and

$B_{3}{ }^{2}=$ the third party's second tier price.

The blend price for third party bids, $B_{3}{ }^{B}$, is simply the average of the first and second-tier bids:

$$
\text { (1A) } B_{3}{ }^{B}=\left(B_{3}{ }^{l}+B_{3}{ }^{2}\right) / 2=\left(B_{3}{ }^{l}+P\right) / 2 \text {. }
$$

The blend price for the treasury share purchaser, $B_{I}{ }^{B}$, is a weighted average, however, because fewer shares are purchased in the first tier than in the second tier of the takeover:

$$
\text { (2A) } \begin{aligned}
B_{I}{ }^{B} & =B_{I}{ }^{l}[(N-T) / 2]+B_{I}{ }^{2}[(N+T) / 2] \\
& =B_{I}{ }^{l}[(N-T) / 2]+P[(N+T) / 2] .
\end{aligned}
$$

Because rational shareholders will tender their shares to the bidder witb the highest blend price, the treasury share purchaser will focus on the costs and benefits of raising its blend price in response to a thirdparty bid. The profits from winning a two-tiered takeover contest will be

$$
N\left(V_{I}-B_{I}{ }^{B}\right)
$$

the profits from losing a two-tiered takeover contest to a third-party bidder are:

6. $(N-T) / 2+T=(N+T) / 2$. 


$$
T\left(B_{3}^{B}-P\right) .
$$

These equations are analogous to equations $(1 \mathrm{~A})$ and $(2 \mathrm{~A})$ in the text except that the relevant choice variable is now the blend price instead of the unitary or single-tier price of the previous analysis. As before in equation (3), the two expressions can be equated to derive the maximum blend price that an initial bidder will offer:

$$
B_{1}{ }^{*}=\left(N V_{1}+P T\right) /(N+T) \text {. }
$$

Analogously, the maximum third-party blend price can be derived:

$$
B_{3}{ }^{* *}=\left(N V_{3}+P T\right) /(N-T) \text {. }
$$

There are also similar foreclosure requirements. A treasury share sale will foreclose third parties from making competitive offers if the initial blend price, $B_{1}{ }^{B I}$, exceeds the reservation blend price, $B_{1}{ }^{B_{*}}$ :

$$
B_{1}^{B I}>B_{1}^{B *} \text {. }
$$

Substituting these maximum blend prices into equations $(1 \mathrm{~A})$ and $(2 \mathrm{~A})$, it is possible to derive the maximum or reservation first tier offers:

$$
\begin{aligned}
& B_{I}{ }^{B *}=\left[2\left(N V_{1}+P T\right)-P(N+T)^{2}\right] /\left(N^{2}-T^{2}\right) .^{7} \\
& B_{I}{ }^{B *}=\left[2 N V_{3}-P(N-T)\right] /(N+T) .^{8}
\end{aligned}
$$

Because of recipient of treasury shares bids for fewer first-tier shares, having a first-tier price higher than other bidders' does not imply a higher blend price. Consequently, rational target shareholders choosing the highest blend price may tender their shares to a third party with a lower front-end offer for more shares. Indeed, if an initial bidder and a third-party bidder equally value a target $\left(V_{1}=V_{3}\right)$, the recipient of treasury shares will have a higher first-tier reservation price $\left(B_{1}^{1 *}>\right.$ $\left.B_{3}{ }^{*}\right)$, but both bidders will have equal reservation blend prices $\left(B_{1}{ }^{*}=\right.$ $\left.B_{3}{ }^{B *}\right)$. The overinsurance standard for foreclosure of higher-valuing third-parties can be equivalently restated in terms of these first-tier reservation prices. Treasury sales will generate foreclosing overinsurance if $B_{1}{ }^{B I}>B_{1}{ }^{B *}$.

7. $B_{l}^{B *}=B_{l}^{l *}[(N-T) / 2]+P[(N+T) / 2]=\left(N V_{l}+P T\right) /(N+T)$.

8. $B_{3}{ }^{B *}=\left(B_{3}{ }^{l *}+P\right) / 2=\left(N V_{3}+P T\right) /(N+T)$. 